\title{
Maternal depression and inflammation during pregnancy
}

\section{Lahti-Pulkkinen, Marius}

2020-08

Lahti-Pulkkinen, M , Girchenko , P , Robinson , R , Lehto , S M , Toffol , E , Heinonen , K, Reynolds, R M , Kajantie , E, Laivuori , H , Villa , P M , Hamalainen , E, Lahti , J \& Raikkonen , K 2020 , ' Maternal depression and inflammation during pregnancy ' , Psychological Medicine , vol. 50 , no. 11 , 0033291719001909 , pp. 1839-1851 . https://doi.org/10.1017/S00332917

https://doi.org/10.1017/S0033291719001909

unspecified

acceptedVersion

Downloaded from Helda, University of Helsinki institutional repository.

This is an electronic reprint of the original article.

This reprint may differ from the original in pagination and typographic detail.

Please cite the original version. 


\section{Psychological Medicine \\ Maternal depression and inflammation during pregnancy \\ --Manuscript Draft--}

Manuscript Number:

Full Title:

Article Type:

Corresponding Author:

Corresponding Author Secondary Information:

Corresponding Author's Institution:

Corresponding Author's Secondary Institution:

First Author:

First Author Secondary Information:

Order of Authors:

Order of Authors Secondary Information:

\section{Manuscript Region of Origin:}

\section{Abstract:}

PSM-D-18-01242R2

Maternal depression and inflammation during pregnancy

Original Article

Marius Lahti-Pulkkinen, Ph.D.

University of Helsinki

Helsinki, FINLAND

University of Helsinki

Marius Lahti-Pulkkinen, Ph.D.

Marius Lahti-Pulkkinen, Ph.D.

Polina Girchenko, Ph.D.

Rachel Robinson, MA

Soili M. Lehto, MD, PhD

Elena Toffol, MD, PhD

Kati Heinonen, PhD

Rebecca M. Reynolds, MD, PhD

Eero Kajantie, MD, PhD

Hannele Laivuori, MD, PhD

Pia M. Villa, MD, PHD

Esa Hämäläinen, $M D, P h D$

Jari Lahti, PhD

Katri Räikkönen, PhD

\section{FINLAND}

Background: Maternal depression during pregnancy increases risk for adverse developmental outcomes in children. However, the underpinning biological mechanisms remain unknown. We tested whether depression was associated with levels of and change in inflammatory state during pregnancy, if early pregnancy overweight/obesity or diabetes/hypertensive pregnancy disorders accounted for/mediated these effects, and if depression added to the inflammation that typically accompanies these conditions.

Methods: We analyzed plasma high-sensitivity C-reactive-protein (hsCRP) and glycoprotein acetyls at three consecutive stages during pregnancy, derived history of depression diagnoses before pregnancy from Care Register for Healthcare (HILMO) $(\mathrm{N}=375)$ and self-reports $(\mathrm{N}=347)$ and depressive symptoms during pregnancy using the Center for Epidemiological Studies Depression Scale completed concurrently to blood samplings $(\mathrm{N}=295)$. Data on early pregnancy body mass index $(\mathrm{BMI})$ and diabetes/hypertensive pregnancy disorders came from medical records. 
Results: Higher overall hsCRP levels, but not change, during pregnancy were predicted by history of depression diagnosis before pregnancy (HILMO: Mean difference $[\mathrm{MD}]=0.69$ Standard deviation(SD) units; 95\%Confidence Interval $(\mathrm{CI})=0.26$ 1.11, self-report: $\mathrm{MD}=0.56 \mathrm{SDs} ; 95 \% \mathrm{Cl}=0.17-0.94)$ and higher depressive symptoms during pregnancy $(0.06 \mathrm{SD}$ per SD increase; $95 \% \mathrm{Cl}=0.00-0.13)$. History of depression diagnosis before pregnancy also predicted higher overall glycoprotein acetyls (HILMO: $\mathrm{MD}=0.52 \mathrm{SDs} ; 95 \% \mathrm{Cl}=0.12-0.93)$. These associations were not explained by diabetes/hypertensive disorders, but were accounted for and mediated by early pregnancy BMI. Furthermore, in obese women, overall hsCRP levels increased as depressive symptoms during pregnancy increased ( $p=0.006$ for interaction).

Conclusions: Depression is associated with a proinflammatory state during pregnancy. These associations are mediated by early pregnancy BMI, and depressive symptoms during pregnancy aggravate the inflammation related to obesity. 


\section{Maternal depression and inflammation during pregnancy}

Marius Lahti-Pulkkinen, $\mathrm{PhD}^{* 1-3}$; Polina Girchenko, $\mathrm{PhD}^{* 1}$; Rachel Robinson, $\mathrm{MA}^{1}$; Soili M. Lehto, MD, PhD, 1,4-6; Elena Toffol, MD, $\mathrm{PhD}^{1-2}$; Kati Heinonen, $\mathrm{PhD}^{1}$; Rebecca M. Reynolds, $\mathrm{MD}, \mathrm{PhD}^{3}$; Eero Kajantie, $\mathrm{MD}, \mathrm{PhD}^{2,7-8}$; Hannele Laivuori, $\mathrm{MD}, \mathrm{PhD}^{9-11}$; Pia M. Villa, MD, PHD ; Esa Hämäläinen, $\mathrm{MD}, \mathrm{PhD}^{12}$; Jari Lahti, $\mathrm{PhD}^{1,13-14}$; Katri Räikkönen, $\mathrm{PhD}^{1}$

* Dr. Lahti-Pulkkinen and Dr. Girchenko had equal contribution and are the joined first authors.

${ }^{1}$ Department of Psychology and Logopedics, Faculty of Medicine, University of Helsinki, Helsinki, Finland; ${ }^{2}$ National Institute for Health and Welfare, Helsinki, Finland; ${ }^{3}$ Centre for Cardiovascular Science, Queen's Medical Research Institute, University of Edinburgh, Edinburgh, United Kingdom; ${ }^{4}$ Institute of Clinical Medicine, University of Eastern Finland, Kuopio, Finland; ${ }^{5}$ Department of Psychiatry, Kuopio University Hospital, Kuopio, Finland; ${ }^{6}$ Department of Psychiatry, Faculty of Medicine, University of Helsinki, Helsinki, Finland; ${ }^{7}$ Children's Hospital, Helsinki University Hospital and University of Helsinki, Helsinki, Finland; ${ }^{8}$ PEDEGO Research Unit, MRC Oulu, Oulu University Hospital and University of Oulu, Oulu, Finland; ${ }^{9}$ Obstetrics and Gynaecology, University of Helsinki and Helsinki University Hospital, University of Helsinki, Helsinki, Finland; ${ }^{10}$ Medical and Clinical Genetics; Institute for Molecular Medicine Finland (FIMM), Helsinki Institute of Life Science; ${ }^{11}$ Faculty of Medicine and Life Sciences, University of Tampere and Department of Obstetrics and Gynecology, Tampere University Hospital, Tampere, Finland; ${ }^{12}$ Department of Clinical Chemistry, University of Helsinki and Helsinki University Hospital, Helsinki, Finland; ${ }^{13}$ Helsinki Collegium for Advanced Studies, University of Helsinki, Helsinki, Finland; ${ }^{14}$ Turku Institute for Advanced Studies, University of Turku, Turku, Finland. Corresponding author: Marius Lahti-Pulkkinen, Department of Psychology and Logopedics, Faculty of Medicine, University of Helsinki, Helsinki, Finland. Haartmaninkatu 3, P.O. Box 9, FI00014 University of Helsinki, Helsinki, Finland; E-mail: marius.lahti-pulkkinen@ helsinki.fi. 
Word count (main text and acknowledgements): 4462.

Conflict of Interest: None.

Financial Support: The PREDO study is funded by the Academy of Finland [grant number 285324, 12848591, 1284859, 1312670, 269925], European Union's Horizon 2020 Award SC12016-RTD-733280 for RECAP, European Commission Dynamics of Inequality Across the Lifecourse: structures and processes (DIAL) No 724363 for PremLife, EVO (a special state subsidy for health science research), University of Helsinki Research Funds, the Signe and Ane Gyllenberg Foundation, Emil Aaltonen Foundation, Finnish Diabetes Research Foundation, Foundation for Cardiovascular Research, Foundation for Pediatric Research, Jane and Aatos Erkko Foundation, Novo Nordisk Foundation, Päivikki and Sakari Sohlberg Foundation, Sigrid Juselius Foundation, and Finnish Medical Foundation. The sponsors played no role in the design or conduct of this study. 


\begin{abstract}
Background: Maternal depression during pregnancy increases risk for adverse developmental outcomes in children. However, the underpinning biological mechanisms remain unknown. We tested whether depression was associated with levels of and change in inflammatory state during pregnancy, if early pregnancy overweight/obesity or diabetes/hypertensive pregnancy disorders accounted for/mediated these effects, and if depression added to the inflammation that typically accompanies these conditions.
\end{abstract}

Methods: We analyzed plasma high-sensitivity C-reactive-protein (hsCRP) and glycoprotein acetyls at three consecutive stages during pregnancy, derived history of depression diagnoses before pregnancy from Care Register for Healthcare (HILMO) $(\mathrm{N}=375)$ and self-reports $(\mathrm{N}=347)$ and depressive symptoms during pregnancy using the Center for Epidemiological Studies Depression Scale completed concurrently to blood samplings $(\mathrm{N}=295)$. Data on early pregnancy body mass index (BMI) and diabetes/hypertensive pregnancy disorders came from medical records.

Results: Higher overall hsCRP levels, but not change, during pregnancy were predicted by history of depression diagnosis before pregnancy (HILMO: Mean difference [MD]=0.69 Standard deviation(SD) units; $95 \%$ Confidence $\quad$ Interval $(\mathrm{CI})=0.26-1.11, \quad$ self-report: $\quad \mathrm{MD}=0.56 \mathrm{SDs}$; 95\% CI=0.17-0.94) and higher depressive symptoms during pregnancy (0.06SD per SD increase; 95\% CI=0.00-0.13). History of depression diagnosis before pregnancy also predicted higher overall glycoprotein acetyls (HILMO: $\mathrm{MD}=0.52 \mathrm{SDs} ; 95 \% \mathrm{CI}=0.12-0.93$ ). These associations were not explained by diabetes/hypertensive disorders, but were accounted for and mediated by early pregnancy BMI. Furthermore, in obese women, overall hsCRP levels increased as depressive symptoms during pregnancy increased ( $\mathrm{p}=0.006$ for interaction).

Conclusions: Depression is associated with a proinflammatory state during pregnancy. These associations are mediated by early pregnancy BMI, and depressive symptoms during pregnancy aggravate the inflammation related to obesity. 


\section{Introduction}

Maternal depression during pregnancy, including major depressive disorder (MDD), dysthymia, and depressive symptoms, is a major pregnancy complication carrying prevalence rates of 7-20\% (Lahti et al., 2017, Woody et al., 2017). Maternal depression not only hinders maternal quality of life, but is often accompanied by overweight/obesity (Kumpulainen et al., 2018), diabetes and hypertensive pregnancy disorders (Fenton and Stover, 2006), and shows high continuity postpartum (Kumpulainen et al., 2018). Maternal depression during pregnancy also associates with poorer fetal growth and preterm birth (Jarde et al., 2016) and increases child risk for inflammation, allergies, asthma, poorer neurodevelopment, and psychopathology (Flanigan et al., 2018, Lahti et al., 2017, Plant et al., 2016, Tuovinen et al., 2018, Van den Bergh et al., 2017).

However, the biological mechanisms underlying the transmission of these effects from the mother to her child remain vague. In addition to depression-related changes in placental structure and function (Lahti-Pulkkinen et al., 2018, Raikkonen et al., 2015, Reynolds et al., 2015), stress axes, oxidative stress and nutrition (Glover, 2015, Van den Bergh et al., 2017), it has been suggested that depression may aggravate maternal proinflammatory state set forth in pregnancy (Leff-Gelman et al., 2016) and link maternal depression with child development (Glover, 2015, Van den Bergh et al., 2017).

By using the Newcastle Ottawa Scale (NOS) (Anthony and Lin, 2018; Herzog et al., 2013; Wells et al., 2014a, 2014b), we systematically assessed the quality of evidence of the scant previous studies that have tested if depression is associated with inflammation during pregnancy. Table ST1 provides a summary of the study characteristics, main findings and NOS quality of evidence assessment. Table ST2 provides further details of the NOS assessment and criteria for cross-sectional (Anthony and Lin, 2018; Herzog et al., 2013) and Table ST3 for cohort studies (Wells et al., 2014a, 2014b). The NOS assessment of the reviewed studies highlights the limited quality of available evidence: of the ten 
reviewed studies 40\% were defined as 'poor' (Azar and Mercer, 2013, Cheng and Pickler, 2014, Gustafsson et al., 2018, Scrandis et al., 2008), 50\% as 'fair' (Cassidy-Bushrow et al., 2012, Christian et al., 2009, Haeri et al., 2013, Osborne et al., 2018, Simpson et al., 2016) and 10\% as 'good' (Blackmore et al., 2011) based on the NOS assessment. Table ST1 also shows that the findings are mixed with some studies showing that maternal depression is associated with higher levels of a number of inflammatory markers studied and some reporting null associations. In the only study providing good quality of evidence, MDD diagnosis and depressive symptoms at 18 and 32 gestational weeks were not significantly associated with interleukin(IL)-6 or tumor necrosis factor alpha (TNF- $\alpha$ ) measured at these same gestational weeks (Blackmore et al., 2011). There were no longitudinal associations across time between depression and inflammation either (Blackmore et al., 2011). Our review, thus, highlights the need for further studies with good quality of evidence to either refute or confirm the hypothesis that depression aggravates the proinflammatory state set forth in pregnancy.

Apart from the limited quality of evidence, there are also critical knowledge gaps in the existing literature. The studies are based on small samples limiting statistical power, and all but two (Azar and Mercer, 2013, Blackmore et al., 2011) have reported cross-sectional correlations, even if depression and/or inflammation would have been measured at more than one gestational stage. In addition to the above-mentioned good quality study (Blackmore et al., 2011), the other, small-scale study reporting longitudinal associations showed in 27 women that an increase in depressive symptoms from 7-10 to 16-20 gestational weeks was associated with higher IL-6 at 16-20 gestational weeks, but the increase was not associated with c-reactive protein (CRP) or TNF- $\alpha$ (Azar and Mercer, 2013). A further knowledge gap relates to the limited evidence available on depression diagnoses: all of the previous studies have focused on depressive symptoms and only three (Blackmore et al., 2011, Haeri et al., 2013, Osborne et al., 2018) have additionally studied depression diagnoses. Moreover, since 
convincing evidence shows associations between depression and obesity in pregnant populations (Kumpulainen et al., 2018, Molyneaux et al., 2014); and inflammatory state in pregnancy is aggravated in response to obesity (Choi et al., 2013), most studies on depression and inflammation during pregnancy have accounted for pre-pregnancy overweight/obesity (Blackmore et al., 2011, Cassidy-Bushrow et al., 2012, Christian et al., 2009, Haeri et al., 2013, Osborne et al., 2018, Simpson et al., 2016). However, few studies have considered diabetes and hypertensive pregnancy disorders (Azar and Mercer, 2013, Haeri et al., 2013, Osborne et al., 2018, Simpson et al., 2016) even though these conditions are associated with depression (Fenton and Stover, 2006), often complicate overweight/obese pregnancies (Ovesen et al., 2011) and associate with increased inflammation as well (Pantham et al., 2015, Rebelo et al., 2013). Finally, none of the studies have tested whether depression adds to the inflammatory effects of overweight/obesity, diabetes and hypertensive pregnancy disorders.

To address these knowledge gaps, we tested the hypotheses that 1) history of depression diagnoses before pregnancy, derived from healthcare registry, and 2) from self-reports, and 3) higher levels of depressive symptoms reported during pregnancy were associated with higher levels of and increases in plasma high-sensitive CRP (hsCRP) and glycoprotein acetyls measured across three consecutive stages during pregnancy. We also tested the hypotheses that early pregnancy body mass index (BMI), diabetes and hypertensive pregnancy disorders accounted for and, at least partially mediated these associations, and tested if depression added to the inflammation that accompany these conditions.

We focused on two proinflammatory biomarkers: hsCRP and glycoprotein acetyls, because they both have long half-lives and indicate systemic, low-grade chronic inflammation (Ritchie et al., 2015). HsCRP is among the most commonly used inflammatory biomarkers in research. Vast evidence in the general population supports its longitudinal associations with depression (Copeland et al., 2012, 
Huang et al., 2019, Valkanova et al., 2013) and cardiovascular mortality (Li et al., 2017). Glycoprotein acetyls are, in turn, a novel inflammatory biomarker. It is a composite signal of changes in multiple circulating glycoproteins. Glycoprotein acetyls predict the risk of infectious illnesses (Ritchie et al., 2015). Importantly, both hsCRP and glycoprotein acetyl levels rise markedly during pregnancy (Wang et al., 2016), making them suitable candidate biomarkers for our study. 


\section{Method}

\section{Sample}

The participants came from the Prediction and Prevention of Pre-eclampsia and Intrauterine Growth Restriction (PREDO) Study, described in detail elsewhere (Girchenko et al., 2017). Briefly, in 20052009, 1079 pregnant women were enrolled to the clinical subsample of the PREDO when they arrived for their first ultrasound screening at 12-13 weeks of gestation. Of them, 969 had one or more and 110 none of the known risk factors for pre-eclampsia and intrauterine growth restriction (IUGR). The study sites comprised 10 hospitals in Southern and Eastern Finland.

Of the 1079 women, 420 underwent venous blood sampling at one to three consecutive stages during pregnancy; due to economic constraints, blood was sampled only at three study hospitals. Because of large within-individual variation in the levels of hsCRP and glycoprotein acetyls across the three samplings, we did not impute missing data ( $\mathrm{n}=41$ with one or two missing blood samples).

Hence, our sample comprised 379 women providing three blood samples taken at median (interquartile range) 13.0 (12.6-13.4), 19.3 (19.0-19.7), and 27.0 (26.6-27.6) gestational weeks. Health registry data on history of depression diagnoses before pregnancy were available for 375 women ( 2 women had no data available and 2 women who received depression diagnosis during pregnancy were excluded); 347 had data on self-reported history of depression diagnosis before pregnancy (29 did not complete the questionnaire and 3 did not specify when they were diagnosed); and 295 women reported depressive symptoms concurrently to the three blood samplings during pregnancy (84 did not complete the symptom questionnaire). Women with these three analytic samples differed from women of the entire sample only in two respects: they were more often younger than 40 years, and less often reported a history of depression diagnosis before pregnancy (Table 1). 
All participants signed written informed consents. The PREDO study protocol was approved by ethics committees of the Helsinki and Uusimaa Hospital District. All study procedures were in accordance with The Code of Ethics of the World Medical Association (Declaration of Helsinki).

\section{Inflammation}

The participants came for blood sampling from antecubital vein between 7-9 AM, after having fasted for at least 10 hours. Plasma was separated immediately. Ethylenediaminetetraacetic acid plasma samples were stored at $-80^{\circ} \mathrm{C}$ until analyzed. The hsCRP concentration $(\mathrm{mg} / \mathrm{L})$ was analyzed with a Beckman-Coulter CRP immunoturbidometric assay and Olympus AU680 analyzer (Beckman Coulter Inc., CA, USA). The intra-assay variation (CV\%) of the method in our laboratory was between $2.6 \%(\mathrm{n}=10$, mean $1.20 \mathrm{mg} / \mathrm{L})$ and $0.7 \%(\mathrm{n}=10$, mean $65 \mathrm{mg} / \mathrm{L})$ and inter-assay variations were $(\mathrm{CV} \%) 3.5 \%(\mathrm{n}=30$, mean $1.07 \mathrm{mg} / \mathrm{l}), 1.2 \%(\mathrm{n}=30$, mean $11.5 \mathrm{mg} / \mathrm{L})$ and $2.9 \%(\mathrm{n}=30$, mean $73 \mathrm{mg} / \mathrm{L}$ ). The limit of detection of the hsCRP method is $0.02 \mathrm{mg} / \mathrm{L}$ and the functional sensitivity was better than $0.1 \mathrm{mg} / \mathrm{L}$. Glycoprotein acetyls $(\mathrm{mmol} / \mathrm{L})$ were analyzed using a high-throughput nuclear magnetic resonance metabolomics platform (1HNMR spectra, Nightingale Ltd.; Espoo, Finland) (Soininen et al., 2015).

\section{Depression}

We derived depression diagnoses from the Care Register for Healthcare (HILMO), comprising diagnoses of all inpatient hospitalizations in Finland since 1969 and outpatient hospitalizations and specialized treatments since 1998; participants were born 1959-1989. Depression diagnoses were identified with the International Classification of Diseases, Tenth-Revision (ICD-10) codes F32-F33, F341 since 1996 and with ICD-9 codes 2961, 2968A, and 3004A in 1987-1995. No women had bipolar disorder in our sample. The median time interval between the last hospital discharge with depression and conception was 3.1 years (Interquartile Range=1.9-6.7 years). 
In early pregnancy, the women answered the question "Have you ever been diagnosed by a physician with depression?" followed by a question on when they were diagnosed.

Starting from 12-13 gestational weeks, the women completed the Center for Epidemiological Studies Depression Scale (CES-D) (Radloff, 1977). The 20 CES-D questions describe depressive symptoms during the past week, rated from none (0) to all (3) of the time. The women completed the CES-D biweekly up to 14 times until 38-39 gestational weeks or delivery. This allowed us to identify the measurements that matched the closest to the three blood samplings for inflammatory biomarkers; for each sampling, we identified two CES-D scores closest to the sampling date. We used the average of these two scores at the three sampling points in our analyses.

Higher CES-D scores indicate more depressive symptoms, and 16 points or more represent probable clinical depression (Radloff, 1977). The CES-D is a well-established measure of depression, and it has been validated in pregnant women (Lahti et al., 2017).

\section{Covariates and Moderators}

Early pregnancy body mass index (BMI), calculated from weight [kilograms $(\mathrm{kg}$ ] and height $[$ meters $(\mathrm{m})]$ measurements verified at the first antenatal clinic visit $[$ Mean $=8.5$, standard deviation $(\mathrm{SD})=1.5$ gestational weeks)], was derived from medical records (overweight $\left[25-29.99 \mathrm{~kg} / \mathrm{m}^{2}\right] /$ obese $\left[\geq 30 \mathrm{~kg} / \mathrm{m}^{2}\right] /$ normal weight $\left[\leq 24.99 \mathrm{~kg} / \mathrm{m}^{2}\right] ;($ WHO, 2000)). Diagnoses of diabetes (type 1 diabetes/gestational diabetes/no diabetes) and hypertensive (chronic hypertension/preeclampsia/gestational hypertension/normotension) pregnancy disorders were derived from medical records and the diagnoses were verified by a clinical jury. Additional covariates included age $(<40$ vs. $\geq 40$ years) and smoking during pregnancy (did not smoke vs. quit during first trimester/smoked throughout pregnancy), derived from medical records and Finnish Medical Birth Register, and 
antenatal alcohol use (yes/no) and education level (basic/secondary vs. tertiary), which were reported in early pregnancy.

\section{Statistical Analyses}

The primary data analytic tool was linear mixed-model regression with hsCRP and glycoprotein acetyls at the three sampling points during pregnancy, analyzed in separate models, as time-varying within-person outcomes. History of depression diagnoses before pregnancy from HILMO and selfreports were treated as time-invariant between-person predictors, and depressive symptoms at the three points matching the blood sampling points as a time-varying within-person predictor. In addition to treating depressive symptoms during pregnancy as continuous, we conducted analyses treating the symptoms as a binary variable indicating probable clinical depression (CES-D $\geq 16)$. All depression indicators were assessed in separate mixed models, which included gestational week at blood sampling as a time-varying within-person predictor and those covariates that were significantly associated with hsCRP and/or glycoprotein acetyls. Interactions of depression (diagnoses or symptoms) x gestational week at blood samplings were added into the models to test if depression predicted changes in hsCRP or glycoprotein acetyls during pregnancy.

We then tested if overweight/obesity, diabetes or hypertensive pregnancy disorders accounted for any effects of depression on inflammation by including the main effects of these conditions into separate mixed-model equations. If the effect sizes of depression attenuated after adjustment for these conditions, we further tested for mediation with the bootstrapping method using 5000 resamples and bias corrected $95 \%$ confidence intervals. These analyses were performed only if the other criteria for mediation were also met: 1) the depression indicator was associated with the condition that attenuated the association and 2) the condition in question was associated with the inflammation marker in question. Finally, to study if depression added to the inflammatory effects of overweight/obesity, 
diabetes or hypertensive pregnancy disorders, we included interaction terms depression x normal weight/overweight/obesity, depression $\mathrm{x}$ diabetes disorders and depression $\mathrm{x}$ hypertensive disorders into the mixed-model equations.

For mixed-models, we used variance components covariance structure and defined a random intercept and random slope for time, i.e., gestational week at blood sampling. Because hsCRP and CES-D distributions were skewed, we normalized hsCRP with logarithm and CES-D with square root transformations. To facilitate interpretation, we transformed all continuous variables to standard deviation (SD) units (for time-varying variables we used the mean of the three data points during pregnancy and its SD to retain within-person variation). To facilitate clinical interpretation, we also provide test statistics in raw units of hsCRP and glycoprotein acetyls.

We conducted sensitivity analyses by excluding measurements of hsCRP and glycoprotein acetyls taken within a month preceding or following acute infectious disease diagnoses derived from HILMO to ascertain that acute infection did not affect our results. The sensitivity analyses included 879-1112 hsCRP and 808-1020 glycoprotein measurements out of the 885-1125 available samples. Infectious illnesses were identified with diagnostic codes as described elsewhere (Kohler et al., 2017, LundSorensen et al., 2016). 


\section{Results}

\section{Background Characteristics}

Table 1 shows the sample characteristics. HsCRP and glycoprotein acetyls were inter-correlated (Pearson r's $\geq 0.38, \mathrm{p}<0.001)$ and showed high rank-order stability across pregnancy $(r \geq 0.75$ for hsCRP and $r \geq 0.72$ for glycoprotein). Figure ST1 shows that levels of hsCRP (Panel A) and glycoprotein acetyls (Panel B) changed during pregnancy; change in hsCRP was A-shaped, whilst glycoprotein acetyls increased linearly across pregnancy. HILMO and self-reported history of depression diagnosis before pregnancy showed concordance (kappa=0.47, $\mathrm{p}<0.001$ ), and both were associated with higher levels of depressive symptoms during pregnancy (diagnosis from HILMO: Mean Difference[MD]=1.00 SD, 95\%CI=0.44-1.56, $\mathrm{p}=0.001$; diagnosis from self-reports: $\mathrm{MD}=1.09$ $\mathrm{SD}, 95 \% \mathrm{CI}=0.64-1.53, \mathrm{p}<0.001)$ and with higher prevalence of probable clinical depression during pregnancy (diagnosis from HILMO: 66.7\% vs. 19.4\%, p<0.001; diagnosis from self-reports: 57.9\% vs. $18.4 \%, \mathrm{p}<0.001)$.

Table ST4 shows that women with lower education, who were overweight or obese in early pregnancy or had chronic hypertension, pre-eclampsia or gestational diabetes had higher overall hsCRP and glycoprotein acetyl levels. HsCRP levels were also higher and changed less across pregnancy in women younger than 40 years $(\beta=0.013$ in older and $\beta=-0.006$ in younger women; $p=0.01$ for age $x$ time interaction). Glycoprotein acetyls increased more across pregnancy in overweight than normal weight women $(\beta=0.08$ in overweight and $\beta=0.07$ in normal weight women; $p=0.01$ for normal weight vs. overweight $\mathrm{x}$ time interaction). Smoking, alcohol use during pregnancy or type 1 diabetes were not associated with hsCRP or glycoprotein acetyls (Table ST4). 
Table 2 shows that hsCRP levels were 0.69 SDs (Mean difference in raw units $[M D]=4.11,95 \%$ Confidence Interval $[\mathrm{CI}]=2.54-5.69 \mathrm{mg} / \mathrm{L})$ and 0.56 SDs $(\mathrm{MD}=2.44,95 \% \mathrm{CI}=1.12-3.77 \mathrm{mg} / \mathrm{L})$ higher in women with compared to those without a history of depression diagnosis before pregnancy derived from HILMO and self-reports, respectively; hsCRP levels were also 0.28 SDs (MD=1.02, $95 \% \mathrm{CI}=0.17-1.88 \mathrm{mg} / \mathrm{L}$ ) higher in women with compared to those without probable clinical depression during pregnancy, and 0.06 SDs higher per each SD increase in these symptoms during pregnancy. Glycoprotein acetyls were $0.52 \mathrm{SDs}(\mathrm{MD}=1.02,95 \% \mathrm{CI}=0.17-1.88 \mathrm{mg} / \mathrm{L})$ higher in women with compared to those without a history of depression diagnosis from HILMO and 0.25 SDs $(\mathrm{MD}=0.05,95 \% \mathrm{CI}=0.003-0.09 \mathrm{mg} / \mathrm{L})$ higher in women with compared to those without probable clinical depression during pregnancy. All associations, except for probable clinical depression during pregnancy with glycoprotein acetyls, remained significant when adjusted for age and education (Table 2) and when adjusted for diabetes and hypertensive pregnancy disorders (Table ST5). However, all associations became non-significant when adjusted for early pregnancy BMI (Table 2). In the models where depression no longer associated with hsCRP, overweight (MD=0.54 SDs between normal weight vs. overweight, 95\% $\mathrm{CI}=0.31-0.97)$ and obesity (MD=1.01 SDs between normal weight vs. obesity, 95\%CI=0.80-1.22) remained significant predictors of hsCRP (respective values for glycoprotein acetyls were $\mathrm{MD}=0.73 \mathrm{SDs}$, 95\% $\mathrm{CI}=0.51-0.97$ and $\mathrm{MD}=0.93 \mathrm{SDs}$, 95\% CI=0.51-1.18). Figures 1-2 display that there were no depression $\mathrm{x}$ gestational week at blood sampling interactions.

The exclusion of hsCRP and glycoprotein measurements taken within one month preceding or following diagnosed infectious diseases did not change the associations (Table ST6). 


\section{Mediation}

Figures ST2--ST4 show that early pregnancy BMI mediated the following effects on hsCRP: history of depression diagnosis before pregnancy from HILMO and from self-reports, and depressive symptoms reported during pregnancy. Figure ST5 shows that BMI also mediated the effect of history of depression diagnosis before pregnancy from HILMO on glycoprotein acetyls. We did not test other possible mediation effects, as the criteria for mediation tests were not met.

\section{Additive Effects}

We found one significant interaction: depressive symptoms during pregnancy interacted significantly with normal weight vs. obesity in the analysis of $\mathrm{hsCRP}$ ( $\mathrm{p}=0.006$ for interaction; $\mathrm{p}=0.57$ for depressive symptoms x normal weight vs. overweight interaction). Figure 3 shows that higher depressive symptoms during pregnancy were associated with higher hsCRP levels in obese women, but not in overweight or normal weight women. This may reflect that below BMI $30 \mathrm{~kg} / \mathrm{m}^{2} \mathrm{hsCRP}$ increased with increasing BMI, but at BMI $30 \mathrm{~kg} / \mathrm{m}^{2}$ and above hsCRP plateaued showing no further increase (Figure ST6). 


\section{Discussion}

We found that depression was associated with higher levels of hsCRP and glycoprotein acetyls during pregnancy. The findings for hsCRP were consistent and significant across the different information sources of depression; whether history of depression diagnosis before pregnancy was derived from HILMO or self-reports, or whether depressive symptoms were reported during pregnancy concurrent to the three consecutive blood samplings, and treated either as a continuous or a binary variable, the latter indicating probable clinical depression during pregnancy. The pattern of findings on glycoprotein acetyls was also consistent across the different information sources, but reached conventional significance levels for the history of depression diagnosis before pregnancy derived from HILMO and for the probable clinical depression reported during pregnancy.

While hsCRP and glycoprotein acetyl levels changed modestly during pregnancy, the associations between depression and these inflammatory biomarkers did not vary across pregnancy. The level of these inflammatory biomarkers have, however, been shown to be markedly higher among women who are than who are not pregnant (Wang et al., 2016). In line, another study has reported that in pregnant women the mean hsCRP levels were above $10 \mathrm{mg} / \mathrm{L}$ at 10.6 gestational weeks (Berggren et $a l ., 2015)$, and yet another study has reported that over $50 \%$ of non-pregnant 31-year-old women have hsCRP values below $1.0 \mathrm{mg} / \mathrm{L}$ (Liukkonen et al., 2011).

Our findings associating depression with higher inflammation among pregnant women correspond with meta-analytic findings from the general population showing longitudinal associations between depression and higher hsCRP and IL-6 levels (Valkanova et al., 2013). Furthermore, in our study the degree of inflammation related to depression was of comparable magnitude to the inflammation associated with early pregnancy overweight, gestational diabetes, and pre-eclampsia. Only the effects of early pregnancy obesity exceeded the degree of depression-related inflammation during pregnancy. 
In raw units, mean differences in hsCRP levels between women with and without depression diagnosis before pregnancy and with and without probable clinical depression during pregnancy were between 1.02 and $4.11 \mathrm{mg} / \mathrm{L}$. This magnitude of inflammation is comparable to the degree of inflammation that has been suggested to increase cardiovascular disease risk moderately in the general population (Li et al., 2017). These findings suggest that depression is associated with a higher proinflammatory state during pregnancy, bearing at least moderate clinical relevance to maternal health and possibly fetal development. To our knowledge, our prospective study is the largest on this topic in sample size thus far, and the first to show such associations using information on depression derived from different sources and three consecutive stages during pregnancy.

The associations between the different depression measures with hsCRP and glycoprotein acetyls were independent of age, education, diabetes and hypertensive pregnancy disorders. However, early pregnancy BMI accounted for and mediated the effects of depression diagnosis before pregnancy and depressive symptoms during pregnancy on inflammation. The mediation via BMI is not surprising, since early pregnancy overweight/obesity and antenatal depression are highly interrelated (Kumpulainen et al., 2018, Molyneaux et al., 2014). Nevertheless, since depression and obesity show continuity across time (Kumpulainen et al., 2018, Simmonds et al., 2016), and the depression-BMIassociation is bi-directional (Luppino et al., 2010), we cannot disentangle whether overweight/obesity preceded depression, or vice versa. Therefore, the mediation findings must be interpreted with caution.

We also found that depressive symptoms during pregnancy added to the inflammatory effects of obesity: among obese women, who had already approximately 1SD higher hsCRP levels throughout pregnancy, hsCRP increased further by 0.19 SDs by each SD increase in depressive symptoms during pregnancy. In overweight and normal weight women, this was not true. Based on the nature of the 
association we found between BMI and hsCRP, we speculate that the strong linear association between BMI and hsCRP between 20 and $30 \mathrm{~kg} / \mathrm{m}^{2}$ leaves no room for depression to independently predict hsCRP in normal weight and overweight women. However, our data suggests that in obese women hsCRP reaches a ceiling: at $30 \mathrm{~kg} / \mathrm{m}^{2}$ and above hsCRP levels plateau, remain consistently high, no longer increasing with increasing BMI. This leaves room for the effects of depressive symptoms, which increase inflammation in obese women even further. Corresponding interactions between obesity and depression on inflammation have also been reported in non-pregnant populations (Ladwig et al., 2003), but our findings are inconsistent with findings from one study of pregnant women that were ethnically diverse from our sample (Cassidy-Bushrow et al., 2012).

Obesity is a well-known proinflammatory state (Choi et al., 2013, Pantham et al., 2015) with the perturbation of intestinal microbiota and changes in intestinal permeability being potential triggers of inflammation (Cox et al., 2015). The secretion of inflammatory cytokines from adipose tissue leads to overexpression of pro-inflammatory cytokines (Hotamisligil, 2006). Obesity indeed mediated most effects of depression on inflammation in our study. However, since inflammation levels increased even further in obese women with higher depressive symptoms during pregnancy, also other factors associated with both depression and inflammation may have contributed to our findings. Genetics and epigenetics and their interactions may contribute, since depression has been associated with both the single-nucleotide polymorphisms and expression of genes regulating inflammatory function (Barnes et al., 2017, Mahajan et al., 2018). These factors may also contribute to the interactions between obesity and depression on inflammation, since evidence suggests shared genetic origins of obesity and depression (Wray et al., 2018). Hypothalamic-pituitary-adrenal (HPA) axis activity may also be involved. Glucocorticoids regulate inflammation by exacerbating the secretion of proinflammatory cytokines and acute phase proteins (Pariante, 2017) and have both pro- and antiinflammatory effects in the brain (Walker and Spencer, 2018). Glucocorticoid functioning is also 
closely associated with depression and obesity (Boggero et al., 2017, Milaneschi et al., 2018, Stetler and Miller, 2011). Findings in smaller subsamples of the PREDO study suggest that depressive symptoms during pregnancy are associated with placental mRNA level changes in genes regulating HPA axis function (Raikkonen et al., 2015, Reynolds et al., 2015). The gut microbiota-brain axis functioning is also intertwined with inflammatory processes, and changes in its function are associated with depression (Alam et al., 2017). Furthermore, depression, obesity and inflammation are each also associated with poorer nutrition, insufficient sleep, physical inactivity and substance use (Ironson et al., 2018, Lai et al., 2015, Lai et al., 2014, Milaneschi et al., 2018, Stubbs et al., 2018). A large Mendelian randomization study found that while CRP concentrations were associated with depression, genetic variation regulating CRP was not (Wium-Andersen et al., 2014). This finding argues against a causal pathway from inflammation to depression and suggests that a common 'residual confounding' factor may possibly underlie the associations found. Hence, the proinflammatory effects of depression and obesity likely stem from multiple contributory factors. Our findings emphasize the need for further studies on these pathways specifically during pregnancy.

Strengths of our study include a large sample size compared to the previous studies, which often included less than 100 participants. We had data on depression from different sources and hsCRP and glycoprotein acetyls were measured at three consecutive stages during pregnancy, which no previous study has had. Furthermore, many previous studies on depression and inflammation during pregnancy utilized very rapidly degrading inflammatory markers, most commonly IL-6. HsCRP is an acutephase protein with a longer half-life than IL-6 (Wirtz et al., 2000) and glycoprotein acetyls display even slower kinetics than hsCRP. Thus, we were able to obtain more stable estimates of the participants' inflammatory state across pregnancy (Ritchie et al., 2015). While the increases in hsCRP and glycoprotein acetyls in pregnancy (Wang et al., 2016) suggest they are suitable markers of antenatal inflammation, having data also on other inflammatory biomarkers would have given further 
insight on the associations of depression and antenatal inflammation. Since glycoprotein acetylation is a mix of a range of proteins (Ritchie et al., 2015), we would also have benefited from data on the specific protein levels. It would also have been informative to have cortisol data to indicate HPA axis activity and other biomarkers that are triggered by inflammation.

The study limitations also include that our sample comprised women at risk for pre-eclampsia and IUGR and that blood samples were available only for a subsample. Furthermore, although diagnostic data from HILMO were available for $99.5 \%$ of women with three blood samples, self-reported diagnostic data were available for $91.6 \%$ and depressive symptoms were reported by $77.8 \%$ of the women. The analytic samples comprised women who were younger and less often self-reported a history of depression diagnoses before pregnancy. These factors limit generalizations of our findings to other samples.

In conclusion, our study showed that depression is associated with a proinflammatory state during pregnancy. These associations are mediated by early pregnancy BMI, and depressive symptoms during pregnancy aggravate the inflammation related to obesity. 


\section{Acknowledgements}

The authors would like to thank the participating women for their contribution to the study, and the University of Helsinki and the participating study hospitals for their support in the conduction of this study. 


\section{References}

Alam, R., Abdolmaleky, H. M. \& Zhou, J. R. (2017). Microbiome, inflammation, epigenetic alterations, and mental diseases. American Journal of Medical Genetics. Part B: Neuropsychiatric Genetics, 174, 651-660.

Azar, R. \& Mercer, D. (2013). Mild depressive symptoms are associated with elevated Creactive protein and proinflammatory cytokine levels during early to midgestation: a prospective pilot study. Journal of Women's Health, 22, 385-389.

Anthony, M., \& Lin, F. (2018). A Systematic Review for Functional Neuroimaging Studies of Cognitive Reserve Across the Cognitive Aging Spectrum. Archives of Clinical Neuropsychology, 33, 937-948.

Barnes, J., Mondelli, V. \& Pariante, C. M. (2017). Genetic Contributions of Inflammation to Depression. Neuropsychopharmacology 42, 81-98.

Berggren, E. K., Roeder, H. A., Boggess, K. A., Moss, K., Offenbacher, S., Campbell, E. \& Grotegut, C. A. (2015). First-Trimester Maternal Serum C-reactive Protein as a Predictor of Third-Trimester Impaired Glucose Tolerance. Reproductive Sciences, 22, 90-93.

Blackmore, E. R., Moynihan, J. A., Rubinow, D. R., Pressman, E. K., Gilchrist, M. \& O'Connor, T. G. (2011). Psychiatric symptoms and proinflammatory cytokines in pregnancy. Psychosomatic Medicine, 73, 656-663.

Boggero, I. A., Hostinar, C. E., Haak, E. A., Murphy, M. L. M. \& Segerstrom, S. C. (2017). Psychosocial functioning and the cortisol awakening response: Meta-analysis, P-curve analysis, and evaluation of the evidential value in existing studies. Biological Psychology, 129, 207-230.

Cassidy-Bushrow, A. E., Peters, R. M., Johnson, D. A. \& Templin, T. N. (2012). Association of depressive symptoms with inflammatory biomarkers among pregnant African-American women. Journal of Reproductive Immunology, 94, 202-209.

Cheng, C. Y. \& Pickler, R. H. (2014). Perinatal stress, fatigue, depressive symptoms, and immune modulation in late pregnancy and one month postpartum. ScientificWorldJournal 2014, 652630 .

Choi, J., Joseph, L. \& Pilote, L. (2013). Obesity and C-reactive protein in various populations: a systematic review and meta-analysis. Obesity Reviews, 14, 232-244.

Christian, L. M., Franco, A., Glaser, R. \& Iams, J. D. (2009). Depressive symptoms are associated with elevated serum proinflammatory cytokines among pregnant women. Brain, Behavior, and Immunity, 23, 750-754.

Copeland, W. E., Shanahan, L., Worthman, C., Angold, A. \& Costello, E. J. (2012). Cumulative Depression Episodes Predict Later C-Reactive Protein Levels: A Prospective Analysis. Biological Psychiatry, 71, 15-21.

Cox, A. J., West, N. P. \& Cripps, A. W. (2015). Obesity, inflammation, and the gut microbiota. The Lancet Diabetes \& Endocrinology, 3, 207-215.

Fenton, W. S. \& Stover, E. S. (2006). Mood disorders: cardiovascular and diabetes comorbidity. Current Opinion in Psychiatry 19, 421-427.

Flanigan, C., Sheikh, A., DunnGalvin, A., Brew, B. K., Almqvist, C. \& Nwaru, B. I. (2018). Prenatal maternal psychosocial stress and offspring's asthma and allergic disease: A systematic review and meta-analysis. Clinical \& Experimental Allergy, 48, 403-414.

Girchenko, P., Lahti, M., Tuovinen, S., Savolainen, K., Lahti, J., Binder, E. B., Reynolds, R. M., Entringer, S., Buss, C., Wadhwa, P. D., Hamalainen, E., Kajantie, E., Pesonen, A. K., Villa, P. M., Laivuori, H. \& Raikkonen, K. (2017). Cohort Profile: Prediction and prevention of preeclampsia and intrauterine growth restriction (PREDO) study. International Journal of Epidemiology 46, 1380-1381g. 
Glover, V. (2015). Prenatal stress and its effects on the fetus and the child: possible underlying biological mechanisms. Advances in Neurobiology, 10, 269-283.

Gustafsson, H. C., Sullivan, E. L., Nousen, E. K., Sullivan, C. A., Huang, E., Rincon, M., Nigg, J. T. \& Loftis, J. M. (2018). Maternal prenatal depression predicts infant negative affect via maternal inflammatory cytokine levels. Brain, Behavior, and Immunity, 73, 470-481.

Haeri, S., Baker, A. M. \& Ruano, R. (2013). Do pregnant women with depression have a proinflammatory profile? Journal of Obstetrics and Gynaecology Research, 39, 948-952.

Herzog, R., Álvarez-Pasquin, M., J., Díaz, C., Del Barrio, J. L., Estrada, J. M., \& Gil, Á. (2013). Are healthcare workers' intentions to vaccinate related to their knowledge, beliefs and attitudes? A systematic review. BMC Public Health 13, 154.

Hotamisligil, G. S. (2006). Inflammation and metabolic disorders. Nature 444, 860.

Huang, M., Su, S., Goldberg, J., Miller, A. H., Levantsevych, O. M., Shallenberger, L., Pimple, P., Pearce, B., Bremner, J. D. \& Vaccarino, V. (2019). Longitudinal association of inflammation with depressive symptoms: A 7-year cross-lagged twin difference study. Brain, Behavior, and Immunity 75, 200-207.

Ironson, G., Banerjee, N., Fitch, C. \& Krause, N. (2018). Positive emotional well-being, health Behaviors, and inflammation measured by C-Reactive protein. Social Science \& Medicine 197, 235-243.

Jarde, A., Morais, M., Kingston, D., Giallo, R., MacQueen, G. M., Giglia, L., Beyene, J., Wang, Y. \& McDonald, S. D. (2016). Neonatal Outcomes in Women With Untreated Antenatal Depression Compared With Women Without Depression: A Systematic Review and Metaanalysis. JAMA Psychiatry 73, 826-837.

Kohler, O., Petersen, L., Mors, O., Mortensen, P. B., Yolken, R. H., Gasse, C. \& Benros, M. E. (2017). Infections and exposure to anti-infective agents and the risk of severe mental disorders: a nationwide study. Acta Psychiatrica Scandinavica, 135, 97-105.

Kumpulainen, S. M., Girchenko, P., Lahti-Pulkkinen, M., Reynolds, R. M., Tuovinen, S., Pesonen, A. K., Heinonen, K., Kajantie, E., Villa, P. M., Hamalainen, E., Laivuori, H. \& Raikkonen, K. (2018). Maternal early pregnancy obesity and depressive symptoms during and after pregnancy. Psychological Medicine, 48, 2353-2363.

Ladwig, K. H., Marten-Mittag, B., Lowel, H., Doring, A. \& Koenig, W. (2003). Influence of depressive mood on the association of CRP and obesity in 3205 middle aged healthy men. Brain, Behavior, and Immunity, 17, 268-75.

Lahti-Pulkkinen, M., Cudmore, M. J., Haeussner, E., Schmitz, C., Pesonen, A. K., Hamalainen, E., Villa, P. M., Mehtala, S., Kajantie, E., Laivuori, H., Reynolds, R. M., Frank, H. G. \& Raikkonen, K. (2018). Placental Morphology Is Associated with Maternal Depressive Symptoms during Pregnancy and Toddler Psychiatric Problems. Scientific Reports, 8, 791.

Lahti, M., Savolainen, K., Tuovinen, S., Pesonen, A. K., Lahti, J., Heinonen, K., Hamalainen, E., Laivuori, H., Villa, P. M., Reynolds, R. M., Kajantie, E. \& Raikkonen, K. (2017). Maternal Depressive Symptoms During and After Pregnancy and Psychiatric Problems in Children. Journal of the American Academy of Child \& Adolescent Psychiatry, 56, 30-39.e7.

Lai, H. M., Cleary, M., Sitharthan, T. \& Hunt, G. E. (2015). Prevalence of comorbid substance use, anxiety and mood disorders in epidemiological surveys, 1990-2014: A systematic review and meta-analysis. Drug and Alcohol Dependence, 154, 1-13.

Lai, J. S., Hiles, S., Bisquera, A., Hure, A. J., McEvoy, M. \& Attia, J. (2014). A systematic review and meta-analysis of dietary patterns and depression in community-dwelling adults. American Journal of Clinical Nutrition, 99, 181-197.

Leff-Gelman, P., Mancilla-Herrera, I., Flores-Ramos, M., Cruz-Fuentes, C., Reyes-Grajeda, J. P., Garcia-Cuetara Mdel, P., Bugnot-Perez, M. D. \& Pulido-Ascencio, D. E. (2016). The 
Immune System and the Role of Inflammation in Perinatal Depression. Neuroscience Bulletin, 32, 398-420.

Li, Y., Zhong, X., Cheng, G., Zhao, C., Zhang, L., Hong, Y., Wan, Q., He, R. \& Wang, Z. (2017). Hs-CRP and all-cause, cardiovascular, and cancer mortality risk: A meta-analysis. Atherosclerosis 259, 75-82.

Liukkonen, T., Rasanen, P., Jokelainen, J., Leinonen, M., Jarvelin, M. R., Meyer-Rochow, V. B. \& Timonen, M. (2011). The association between anxiety and C-reactive protein (CRP) levels: results from the Northern Finland 1966 birth cohort study. European Psychiatry 26, 363-369.

Lund-Sorensen, H., Benros, M. E., Madsen, T., Sorensen, H. J., Eaton, W. W., Postolache, T. T., Nordentoft, M. \& Erlangsen, A. (2016). A Nationwide Cohort Study of the Association Between Hospitalization With Infection and Risk of Death by Suicide. JAMA Psychiatry 73, 912919.

Luppino, F. S., de Wit, L. M., Bouvy, P. F., Stijnen, T., Cuijpers, P., Penninx, B. W. \& Zitman, F. G. (2010). Overweight, obesity, and depression: a systematic review and meta-analysis of longitudinal studies. Archives of General Psychiatry, 67, 220-229.

Mahajan, G. J., Vallender, E. J., Garrett, M. R., Challagundla, L., Overholser, J. C., Jurjus, G., Dieter, L., Syed, M., Romero, D. G., Benghuzzi, H. \& Stockmeier, C. A. (2018). Altered neuroinflammatory gene expression in hippocampus in major depressive disorder. Progress in Neuro-Psychopharmacology \& Biological Psychiatry, 82, 177-186.

Milaneschi, Y., Simmons, W. K., van Rossum, E. F. C. \& Penninx, B. W. (2019). Depression and obesity: evidence of shared biological mechanisms. Molecular Psychiatry, 29, 24-33.

Molyneaux, E., Poston, L., Ashurst-Williams, S. \& Howard, L. M. (2014). Pre-pregnancy obesity and mental disorders during pregnancy and postpartum: A systematic review and meta-analysis. Pregnancy Hypertension, 4, 236.

Osborne, S., Biaggi, A., Chua, T. E., Du Preez, A., Hazelgrove, K., Nikkheslat, N., Previti, G., Zunszain, P. A., Conroy, S. \& Pariante, C. M. (2018). Antenatal depression programs cortisol stress reactivity in offspring through increased maternal inflammation and cortisol in pregnancy: The Psychiatry Research and Motherhood - Depression (PRAM-D) Study. Psychoneuroendocrinology, 98, 211-236.

Ovesen, P., Rasmussen, S. \& Kesmodel, U. (2011). Effect of prepregnancy maternal overweight and obesity on pregnancy outcome. Obstetrics \& Gynecology, 118, 305-312.

Pantham, P., Aye, I. L. \& Powell, T. L. (2015). Inflammation in maternal obesity and gestational diabetes mellitus. Placenta 36, 709-715.

Pariante, C. M. (2017). Why are depressed patients inflamed? A reflection on 20 years of research on depression, glucocorticoid resistance and inflammation. European Neuropsychopharmacology, 27, 554-559.

Plant, D. T., Pawlby, S., Sharp, D., Zunszain, P. A. \& Pariante, C. M. (2016). Prenatal maternal depression is associated with offspring inflammation at 25 years: a prospective longitudinal cohort study. Translational Psychiatry 6, e936.

Radloff, L. S. (1977). The CES-D Scale: A Self-Report Depression Scale for Research in the General Population. Applied Psychological Measurement 1, 385-401.

Raikkonen, K., Pesonen, A. K., O'Reilly, J. R., Tuovinen, S., Lahti, M., Kajantie, E., Villa, P., Laivuori, H., Hamalainen, E., Seckl, J. R. \& Reynolds, R. M. (2015). Maternal depressive symptoms during pregnancy, placental expression of genes regulating glucocorticoid and serotonin function and infant regulatory behaviors. Psychological Medicine, 45, 3217-3226.

Rebelo, F., Schlussel, M. M., Vaz, J. S., Franco-Sena, A. B., Pinto, T. J., Bastos, F. I., Adegboye, A. R. \& Kac, G. (2013). C-reactive protein and later preeclampsia: systematic review and metaanalysis taking into account the weight status. Journal of Hypertension, 31, 16-26. 
Reynolds, R. M., Pesonen, A. K., O'Reilly, J. R., Tuovinen, S., Lahti, M., Kajantie, E., Villa, P. M., Laivuori, H., Hamalainen, E., Seckl, J. R. \& Raikkonen, K. (2015). Maternal depressive symptoms throughout pregnancy are associated with increased placental glucocorticoid sensitivity. Psychological Medicine, 45, 2023-2030.

Ritchie, Scott C., Würtz, P., Nath, Artika P., Abraham, G., Havulinna, Aki S., Fearnley, Liam G., Sarin, A.-P., Kangas, Antti J., Soininen, P., Aalto, K., Seppälä, I., Raitoharju, E., Salmi, M., Maksimow, M., Männistö, S., Kähönen, M., Juonala, M., Ripatti, S., Lehtimäki, T., Jalkanen, S., Perola, M., Raitakari, O., Salomaa, V., Ala-Korpela, M., Kettunen, J. \& Inouye, M. (2015). The Biomarker GlycA Is Associated with Chronic Inflammation and Predicts LongTerm Risk of Severe Infection. Cell Systems 1, 293-301.

Scrandis, D. A., Langenberg, P., Tonelli, L. H., Sheikh, T. M., Manogura, A. C., Alberico, L. A., Hermanstyne, T., Fuchs, D., Mighty, H., Hasday, J. D., Boteva, K. \& Postolache, T. T. (2008). Prepartum Depressive Symptoms Correlate Positively with C-Reactive Protein Levels and Negatively with Tryptophan Levels: A Preliminary Report. International Journal of Child Health and Human Development : IJCHD, 1, 167-174.

Simmonds, M., Llewellyn, A., Owen, C. G. \& Woolacott, N. (2016). Predicting adult obesity from childhood obesity: a systematic review and meta-analysis. Obesity Reviews, 17, 95-107.

Simpson, W., Steiner, M., Coote, M. \& Frey, B. N. (2016). Relationship between inflammatory biomarkers and depressive symptoms during late pregnancy and the early postpartum period: a longitudinal study. Brazilian Journal of Psychiatry, 38, 190-196.

Soininen, P., Kangas, A. J., Wurtz, P., Suna, T. \& Ala-Korpela, M. (2015). Quantitative serum nuclear magnetic resonance metabolomics in cardiovascular epidemiology and genetics. Circulation: Cardiovascular Genetics, 8, 192-206.

Stetler, C. \& Miller, G. E. (2011). Depression and hypothalamic-pituitary-adrenal activation: a quantitative summary of four decades of research. Psychosomatic Medicine, 73, 114-126.

Stubbs, B., Vancampfort, D., Firth, J., Schuch, F. B., Hallgren, M., Smith, L., Gardner, B., Kahl, K. G., Veronese, N., Solmi, M., Carvalho, A. F. \& Koyanagi, A. (2018). Relationship between sedentary behavior and depression: A mediation analysis of influential factors across the lifespan among 42,469 people in low- and middle-income countries. Journal of Affective Disorders, 229, 231-238.

Tuovinen, S., Lahti-Pulkkinen, M., Girchenko, P., Lipsanen, J., Lahti, J., Heinonen, K., Reynolds, R. M., Hamalainen, E., Kajantie, E., Laivuori, H., Pesonen, A. K., Villa, P. M. \& Raikkonen, K. (2018). Maternal depressive symptoms during and after pregnancy and child developmental milestones. Depression and Anxiety, 35, 732-741.

Valkanova, V., Ebmeier, K. P. \& Allan, C. L. (2013). CRP, IL-6 and depression: a systematic review and meta-analysis of longitudinal studies. Journal of Affective Disorders, 150, 736-744.

Walker, D. J. \& Spencer, K. A. (2018). Glucocorticoid programming of neuroimmune function. Genetic and Comparative Endocrinology, 256, 80-88.

Van den Bergh, B. R. H., van den Heuvel, M. I., Lahti, M., Braeken, M., de Rooij, S. R., Entringer, S., Hoyer, D., Roseboom, T., Raikkonen, K., King, S. \& Schwab, M. (2017). Prenatal developmental origins of behavior and mental health: The influence of maternal stress in pregnancy. Neuroscience and Biobehavioral Reviews, doi: 10.1016/j.neubiorev.2017.07.003.

Wang, Q., Würtz, P., Auro, K., Mäkinen, V.-P., Kangas, A. J., Soininen, P., Tiainen, M., Tynkkynen, T., Jokelainen, J., Santalahti, K., Salmi, M., Blankenberg, S., Zeller, T., Viikari, J., Kähönen, M., Lehtimäki, T., Salomaa, V., Perola, M., Jalkanen, S., Järvelin, M.-R., Raitakari, O. T., Kettunen, J., Lawlor, D. A. \& Ala-Korpela, M. (2016). Metabolic profiling of pregnancy: cross-sectional and longitudinal evidence. BMC medicine 14, 205. 
Wells, G., Shea, B., O'Connell, D., Peterson, J., Welch, V., Losos, M. \& Tugwell, P. (2014a). Newcastle-Ottawa quality assessment form for cohort studies. E17-E18. http://www.ncbi.nlm.nih.gov/books/NBK115843/bin/appe-fm3.pdf

Wells, G., Shea, B., O'Connell, D., Peterson, J., Welch, V., Losos, M. \& Tugwell, P. (2014b). The Newcastle-Ottawa Scale (NOS) for assessing the quality of nonrandomised studies in metaanalyses. http://www.ohri.ca/programs/clinical epidemiology/oxford.asp.

WHO (2000). Obesity: preventing and managing the global epidemic. Report of a WHO consultation. World Health Organization Technical Report Series, 894, i-xii, 1-253.

Wirtz, D. C., Heller, K. D., Miltner, O., Zilkens, K. W. \& Wolff, J. M. (2000). Interleukin-6: a potential inflammatory marker after total joint replacement. International Orthopaedics, 24, 194-196.

Wium-Andersen, M. K., Orsted, D. D. \& Nordestgaard, B. G. (2014). Elevated C-reactive protein, depression, somatic diseases, and all-cause mortality: a mendelian randomization study. Biological Psychiatry, 76, 249-57.

Woody, C. A., Ferrari, A. J., Siskind, D. J., Whiteford, H. A. \& Harris, M. G. (2017). A systematic review and meta-regression of the prevalence and incidence of perinatal depression. Journal of Affective Disorders, 219, 86-92.

Wray, N. R., Ripke, S., Mattheisen, M., Trzaskowski, M., Byrne, E. M., Abdellaoui, A., Adams, M. J., Agerbo, E., Air, T. M., Andlauer, T. M. F., Bacanu, S. A., Baekvad-Hansen, M., Beekman, A. F. T., Bigdeli, T. B., Binder, E. B., Blackwood, D. R. H., Bryois, J., Buttenschon, H. N., Bybjerg-Grauholm, J., Cai, N., Castelao, E., Christensen, J. H., Clarke, T. K., Coleman, J. I. R., Colodro-Conde, L., Couvy-Duchesne, B., Craddock, N., Crawford, G. E., Crowley, C. A., Dashti, H. S., Davies, G., Deary, I. J., Degenhardt, F., Derks, E. M., Direk, N., Dolan, C. V., Dunn, E. C., Eley, T. C., Eriksson, N., Escott-Price, V., Kiadeh, F. H. F., Finucane, H. K., Forstner, A. J., Frank, J., Gaspar, H. A., Gill, M., Giusti-Rodriguez, P., Goes, F. S., Gordon, S. D., Grove, J., Hall, L. S., Hannon, E., Hansen, C. S., Hansen, T. F., Herms, S., Hickie, I. B., Hoffmann, P., Homuth, G., Horn, C., Hottenga, J. J., Hougaard, D. M., Hu, M., Hyde, C. L., Ising, M., Jansen, R., Jin, F., Jorgenson, E., Knowles, J. A., Kohane, I. S., Kraft, J., Kretzschmar, W. W., Krogh, J., Kutalik, Z., Lane, J. M., Li, Y., Li, Y., Lind, P. A., Liu, X., Lu, L., MacIntyre, D. J., MacKinnon, D. F., Maier, R. M., Maier, W., Marchini, J., Mbarek, H., McGrath, P., McGuffin, P., Medland, S. E., Mehta, D., Middeldorp, C. M., Mihailov, E., Milaneschi, Y., Milani, L., Mill, J., Mondimore, F. M., Montgomery, G. W., Mostafavi, S., Mullins, N., Nauck, M., Ng, B., Nivard, M. G., Nyholt, D. R., O'Reilly, P. F., Oskarsson, H., Owen, M. J., Painter, J. N., Pedersen, C. B., Pedersen, M. G., Peterson, R. E., Pettersson, E., Peyrot, W. J., Pistis, G., Posthuma, D., Purcell, S. M., Quiroz, J. A., Qvist, P., Rice, J. P., Riley, B. P., Rivera, M., Saeed Mirza, S., Saxena, R., Schoevers, R., Schulte, E. C., Shen, L., Shi, J., Shyn, S. I., Sigurdsson, E., Sinnamon, G. B. C., Smit, J. H., Smith, D. J., Stefansson, H., Steinberg, S., Stockmeier, C. A., Streit, F., Strohmaier, J., Tansey, K. E., Teismann, H., Teumer, A., Thompson, W., Thomson, P. A., Thorgeirsson, T. E., Tian, C., Traylor, M., Treutlein, J., Trubetskoy, V., Uitterlinden, A. G., Umbricht, D., Van der Auwera, S., van Hemert, A. M., Viktorin, A., Visscher, P. M., Wang, Y., Webb, B. T., Weinsheimer, S. M., Wellmann, J., Willemsen, G., Witt, S. H., Wu, Y., Xi, H. S., Yang, J., Zhang, F., Arolt, V., Baune, B. T., Berger, K., Boomsma, D. I., Cichon, S., Dannlowski, U., de Geus, E. C. J., DePaulo, J. R., Domenici, E., Domschke, K., Esko, T., Grabe, H. J., Hamilton, S. P., Hayward, C., Heath, A. C., Hinds, D. A., Kendler, K. S., Kloiber, S., Lewis, G., Li, Q. S., Lucae, S., Madden, P. F. A., Magnusson, P. K., Martin, N. G., McIntosh, A. M., Metspalu, A., Mors, O., Mortensen, P. B., Muller-Myhsok, B., Nordentoft, M., Nothen, M. M., O'Donovan, M. C., Paciga, S. A., Pedersen, N. L., Penninx, B., Perlis, R. H., Porteous, D. J., Potash, J. B., Preisig, M., Rietschel, M., Schaefer, C., Schulze, T. G., Smoller, J. W., Stefansson, K., Tiemeier, H., Uher, R., Volzke, H., Weissman, M. M., Werge, T., Winslow, A. R., Lewis, C. 
M., Levinson, D. F., Breen, G., Borglum, A. D. \& Sullivan, P. F. (2018). Genome-wide association analyses identify 44 risk variants and refine the genetic architecture of major depression. Nature Genetics, 50, 668-681. 


\begin{tabular}{|c|c|c|c|c|c|c|c|c|c|c|c|}
\hline & \multicolumn{2}{|c|}{ Entire sample (N=1079) } & \multicolumn{3}{|c|}{$\begin{array}{l}\text { Sample with } 3 \text { high-sensitivity } \mathrm{C} \text { - } \\
\text { reactive protein blood samples and } \\
\text { data on history of depression } \\
\text { diagnosis before pregnancy from } \\
\text { HILMO }(\mathrm{N}=375)\end{array}$} & \multicolumn{3}{|c|}{$\begin{array}{l}\text { Sample with } 3 \text { high-sensitivity } \mathrm{C} \text { - } \\
\text { reactive protein blood samples and } \\
\text { data on depression diagnosis before } \\
\text { pregnancy from self-reports }(\mathrm{N}=347)\end{array}$} & \multicolumn{3}{|c|}{$\begin{array}{c}\text { Sample with } 3 \text { high-sensitivity } \mathrm{C} \text { - } \\
\text { reactive protein blood samples and } \\
\text { data on depressive symptoms reported } \\
\text { concurrently to the blood samplings } \\
\text { during pregnancy }(\mathrm{N}=295)\end{array}$} \\
\hline & $\begin{array}{r}\operatorname{Mean} / \mathbf{N} \\
(\mathrm{SD} / \%)\end{array}$ & Range & $\begin{array}{r}\operatorname{Mean} / \mathbf{N} \\
(\mathrm{SD} / \%)\end{array}$ & Range & $\mathbf{P 1}$ & $\begin{array}{r}\text { Mean/N } \\
(\mathrm{SD} / \%)\end{array}$ & Range & $\mathbf{P 2}$ & $\begin{array}{r}\operatorname{Mean} / \mathbf{N} \\
(\mathrm{SD} / \%)\end{array}$ & Range & P3 \\
\hline Age (years) & $33.2(5.8)$ & $17.2-47.4$ & $32.6(5.2)$ & $19.5-47.4$ & 0.14 & $32.6(5.1)$ & $19.5-47.4$ & 0.08 & $32.6(5.1)$ & $20.3-47.4$ & 0.11 \\
\hline$<40$ years, $\mathrm{n}(\%)$ & $902(83.6 \%)$ & & $337(89.9 \%)$ & & 0.003 & $312(89.9 \%)$ & & 0.006 & $265(89.8 \%)$ & & 0.008 \\
\hline$\geq 40$ years, $n(\%)$ & $177(16.4 \%)$ & & $38(10.1 \%)$ & & & $35(10.1 \%)$ & & & $30(10.2 \%)$ & & \\
\hline Data not available, n (\%) & 0 & & 0 & & & 0 & & & 0 & & \\
\hline Education & & & & & 0.71 & & & 0.46 & & & 0.79 \\
\hline Lower secondary or lower & $483(46.1 \%)$ & & $181(48.7 \%)$ & & & $169(48.7 \%)$ & & & $139(47.1 \%)$ & & \\
\hline Upper secondary or tertiary & $564(53.9 \%)$ & & $191(51.3 \%)$ & & & $178(51.3 \%)$ & & & $156(52.9 \%)$ & & \\
\hline Data not available, n (\%) & 32 & & 3 & & & 0 & & & 0 & & \\
\hline Data not available, n (\%) & 0 & & 0 & & & 0 & & & 0 & & \\
\hline Smoking during pregnancy & & & & & 0.49 & & & 0.46 & & & 0.80 \\
\hline No & $1025(95.4 \%)$ & & $351(93.9 \%)$ & & & $324(93.6 \%)$ & & & $277(94.2 \%)$ & & \\
\hline Quit during first trimester & $39(3.6 \%)$ & & $17(4.6 \%)$ & & & $17(4.9 \%)$ & & & $14(4.8 \%)$ & & \\
\hline Smoked throughout pregnancy & $11(1.0 \%)$ & & $6(1.6 \%)$ & & & $5(1.5 \%)$ & & & $3(1.0 \%)$ & & \\
\hline Data not available, n (\%) & 4 & & 1 & & & 1 & & & 1 & & \\
\hline Alcohol use during pregnancy & & & & & 0.23 & & & 0.30 & & & 0.10 \\
\hline No & $776(71.9 \%)$ & & $295(86.0 \%)$ & & & $285(85.6 \%)$ & & & $252(87.2 \%)$ & & \\
\hline Yes & $158(14.6 \%)$ & & $48(14.0 \%)$ & & & $48(14.4 \%)$ & & & $37(12.8 \%)$ & & \\
\hline Data not available, n (\%) & 145 & & 32 & & & 14 & & & 6 & & \\
\hline $\begin{array}{l}\text { Body Mass Index in early } \\
\text { pregnancy }\left(\mathrm{kg} / \mathrm{m}^{2}\right)\end{array}$ & $27.4(6.5)$ & $17.2-55.0$ & $27.1(6.6)$ & $17.6-55.0$ & 0.44 & $27.1(6.7)$ & $17.6-55.0$ & 0.46 & $26.7(6.7)$ & $17.7-55.0$ & 0.10 \\
\hline Normal weight $\left(<24.99 \mathrm{~kg} / \mathrm{m}^{2}\right)$ & $503(46.6 \%)$ & & $183(48.8 \%)$ & & 0.15 & $171(49.3 \%)$ & & 0.26 & $153(51.9 \%)$ & & 0.08 \\
\hline Overweight $\left(25-29.99 \mathrm{~kg} / \mathrm{m}^{2}\right)$ & $193(17.9 \%)$ & & $78(20.8 \%)$ & & & $69(19.9 \%)$ & & & $58(19.7 \%)$ & & \\
\hline Obese $\left(\geq 30 \mathrm{~kg} / \mathrm{m}^{2}\right)$ & $383(35.5 \%)$ & & $114(30.4 \%)$ & & & $107(30.8 \%)$ & & & $84(28.5 \%)$ & & \\
\hline Data not available, n (\%) & 0 & & 0 & & & 0 & & & 0 & & \\
\hline $\begin{array}{l}\text { Hypertensive disorders in } \\
\text { pregnancy }\end{array}$ & & & & & 0.87 & & & 0.32 & & & 0.37 \\
\hline Normotension & $705(65.5 \%)$ & & $237(63.2 \%)$ & & & $222(64.1 \%)$ & & & $192(65.1 \%)$ & & \\
\hline
\end{tabular}




\section{Gestational hypertension}

Pre-eclampsia

Chronic hypertension

Data not available, n (\%)

Diabetes disorders in pregnancy

$$
\text { No }
$$

Gestational diabetes

Type 1 diabetes

Data not available, n (\%)

History of depression diagnosis before pregnancy

from HILMO

No
Yes
Data not available, n $(\%)$

$1033(96.1 \%)$ $39(3.6 \%)$

4

from self-reports

$\begin{array}{ll}\text { No } & 827(89.6 \%) \\ \text { Yes } & 96(10.4 \%) \\ \text { Data not available, n (\%) } & 156\end{array}$

Depressive symptoms

during pregnancy

continuous score (mean of

reports at 3 blood

sampling points)

binary score (continuous

score $\geq 16$, probable clinical

depression)

No
Yes
Data not available, n $(\%)$

$609(78.9 \%)$

$163(21.1 \%)$

307

High-sensitivity C-reactive

protein $(\mathrm{mg} / \mathrm{L})$, Median

(Interquartile Range)

First sampling point

(11.1-16.7 gestational weeks)

Data not available, n (\%)

Second sampling point

669

$\begin{array}{ll}36(9.6 \%) & 34(9.8 \%) \\ 37(9.9 \%) & 33(9.5 \%) \\ 65(17.3 \%) & 58(16.7 \%) \\ 0 & 0 \\ 288(76.8 \%) & 0.66 \\ 78(20.8 \%) & \\ 9(2.4 \%) & 268(77.2 \%) \\ 0 & 72(20.8) \\ & 7(2.0 \%) \\ & 0\end{array}$

0.81

$329(95.1 \%)$

$17(4.9 \%)$

$18(4.8 \%)$

0

$322(93.3 \%)$

$23(6.7 \%)$

30

$$
\text { 0.5-44.7 } 11.51(7.11)
$$

$0.3-45.0$

0.72

$229(78.7 \%)$

$62(21.3 \%)$

84

$3.81(2.18-7.34)$

$0.23-32.70$

$3.83(2.22-7.40)$

$0.23-32.70$

0.86

$4.53(2.42-8.69) \quad 0.31-60.65 \quad 4.56(2.37-8.95) \quad 0.31-60.65 \quad 0.83$
0.80

0.04

$324(93.4 \%)$

$23(6.6 \%)$

0

$11.54(7.15)$

$0.33-45.0$

0.76

$10.58(10.5)$

0.99

$221(78.9 \%)$

$59(21.1 \%)$

67

0

$3.80(2.12-7.34) \quad 0.23-32.70 \quad 0.94$

0

$4.50(2.33-8.71) \quad 0.31-60.65 \quad 0.83 \quad 4.30(2.30-7.97) \quad 0.31-60.65$
$0.33-45.0$

0.78

$231(78.3 \%)$

$64(21.7 \%)$

$19(6.8 \%)$

15

$80(2.12-7.11) \quad 0.23-31.49 \quad 0.90$ 
(17.1-22.9 gestational weeks)

Data not available, n (\%)

674

0

Third sampling point

(25.3-31.1 gestational weeks)

Data not available, n $(\%)$

Glycoprotein acetyls (mmol/l)*

First sampling point

(11.1-16.7 gestational weeks)

Data not available, n (\%)

Second sampling point

(17.1-22.9 gestational weeks)

Data not available, n (\%)

Third sampling point

(25.3-31.1 gestational weeks)

Data not available, n (\%)

$1.26(0.16)$

$1.34(0.18)$

679
$677 \quad 0 \quad 0$

$0.89-1.85 \quad 1.27(0.16)$

$0.89-1.85$

$0.40 \quad 1.26(0.16)$

31

0.94-2.14 $1.35(0.17)$

$1.0-2.14$

$0.44 \quad 1.35(0.17)$

31

31

$1.06-2.25 \quad 1.45(0.18)$

$1.06-2.25 \quad 1.0 \quad 1.44(0.17)$

31

31
0

$3.72(1.98-6.37) \quad 0.22-26.10$

0.39

0

24

1.3

$0.45 \quad 1$.

Depressive symptoms during pregnancy in the entire sample are report

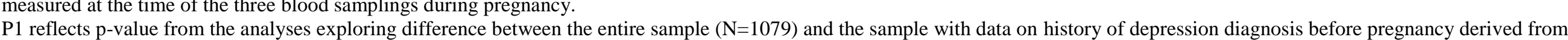

HILMO (N=375).

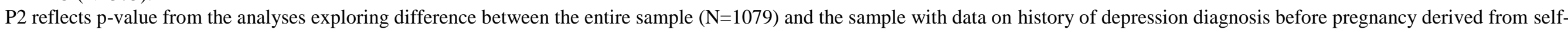
reports $(\mathrm{N}=348)$.

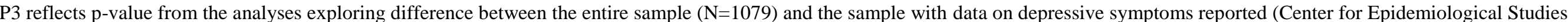
Depression Scale) at the time of the three blood samplings during pregnancy $(\mathrm{N}=295)$.

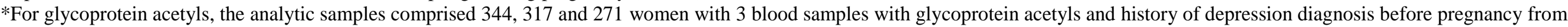

HILMO and from self-reports and depressive symptoms reported concurrent to the blood samplings during pregnancy, respectively.

HILMO refers to Care Register for Healthcare. 
Table 2. Associations of a history of depression diagnosis before pregnancy derived from the Care Register for Healthcare (HILMO) and self-reports, and depressive symptoms and probable clinical depression reported during pregnancy with high sensitivity $\mathrm{C}$-Reactive protein and glycoprotein acetyls across the three measurement points during pregnancy.

\begin{tabular}{|c|c|c|c|c|c|c|c|c|c|}
\hline & \multicolumn{3}{|c|}{ Model 1} & \multicolumn{3}{|c|}{ Model 2} & \multicolumn{3}{|c|}{ Model 3} \\
\hline & $\begin{array}{l}\text { Estimate in } \\
\text { SD units* }\end{array}$ & $95 \% \mathrm{CI}$ & $\mathrm{P}$ & $\begin{array}{l}\text { Estimate in } \\
\text { SD units* }\end{array}$ & $95 \% \mathrm{CI}$ & $\mathrm{P}$ & $\begin{array}{l}\text { Estimate in } \\
\text { SD units* }\end{array}$ & $95 \% \mathrm{CI}$ & $\mathrm{P}$ \\
\hline \multicolumn{10}{|c|}{ High-sensitivity C-reactive protein (SD units) (outcome) } \\
\hline \multicolumn{10}{|c|}{$\begin{array}{l}\text { History of depression diagnosis } \\
\text { before pregnancy (yes vs. no) }\end{array}$} \\
\hline from HILMO & 0.69 & $0.26,1.11$ & 0.002 & 0.50 & $0.08,0.92$ & 0.02 & 0.16 & $-0.21,0.53$ & 0.40 \\
\hline from self-reports & 0.56 & $0.17,0.94$ & 0.005 & 0.47 & $0.10,0.85$ & 0.01 & 0.28 & $-0.05,0.60$ & 0.09 \\
\hline \multicolumn{10}{|l|}{$\begin{array}{l}\text { Depressive symptoms } \\
\text { during pregnancy }\end{array}$} \\
\hline continuous score (SD units) & 0.06 & $0.00,0.13$ & 0.05 & 0.06 & $0.00,0.13$ & 0.05 & 0.05 & $-0.01,0.11$ & 0.14 \\
\hline $\begin{array}{l}\text { binary score (continuous } \\
\text { score } \geq 16, \text { probable clinical } \\
\text { depression vs. continuous } \\
\text { score }<16 \text {, no probable clinical } \\
\text { depression) }\end{array}$ & 0.28 & $0.03,0.53$ & 0.03 & 0.28 & $0.04,0.52$ & 0.02 & 0.20 & $-0.01,0.42$ & 0.06 \\
\hline \multicolumn{10}{|c|}{ Glycoprotein acetyls (SD units) (outcome) } \\
\hline \multicolumn{10}{|l|}{$\begin{array}{l}\text { History of depression diagnosis } \\
\text { before pregnancy (yes vs. no) }\end{array}$} \\
\hline from HILMO & 0.52 & $0.12,0.93$ & 0.01 & 0.42 & $0.01,0.84$ & 0.04 & 0.04 & $-0.32,0.39$ & 0.84 \\
\hline from self-reports & 0.30 & $-0.06,0.66$ & 0.10 & 0.24 & $-0.11,0.60$ & 0.18 & 0.04 & $-0.26,0.34$ & 0.78 \\
\hline \multicolumn{10}{|l|}{$\begin{array}{l}\text { Depressive symptoms } \\
\text { during pregnancy }\end{array}$} \\
\hline continuous score (SD units) & 0.05 & $-0.01,0.11$ & 0.10 & 0.05 & $-0.01,0.11$ & 0.10 & 0.04 & $-0.02,0.09$ & 0.23 \\
\hline $\begin{array}{l}\text { binary score (continuous } \\
\text { score } \geq 16 \text {, probable clinical } \\
\text { depression vs. continuous } \\
\text { score }<16 \text {, no probable clinical } \\
\text { depression) }\end{array}$ & 0.25 & $0.02,0.46$ & 0.04 & 0.25 & $0.02,0.48$ & 0.03 & 0.19 & $-0.008,0.38$ & 0.06 \\
\hline \multicolumn{10}{|c|}{$\begin{array}{l}\text { Note. *Estimates and 95\% Confidence Intervals (95\% CI) reflect differences between those with and without a history of depression diagnosis before pregnancy or with and } \\
\text { without probable clinical depression during pregnancy in high-sensitivity C-reactive protein (hsCRP) and glycoprotein acetyls in standard deviation (SD) units or change in SD } \\
\text { units in hsCRP and glycoprotein acetyls per SD unit change in the continuous depressive symptom scores during pregnancy. } \\
\text { Model } 1 \text { is unadjusted for covariates but includes the gestational week when blood was sampled as a within-person time-varying predictor, Model } 2 \text { is Model } 1+\text { age and } \\
\text { education, Model } 3 \text { is Model } 2+\text { body mass index in early pregnancy (categorized as normal weight }\left[<25 \mathrm{~kg} / \mathrm{m}^{2}\right], \text { overweight }\left[25-29.99 \mathrm{~kg} / \mathrm{m}^{2}\right] \text { and obese }\left[\geq 30 \mathrm{~kg} / \mathrm{m}^{2}\right] \text { ). }\end{array}$} \\
\hline
\end{tabular}




\section{Figure Legends}

\section{Figure 1.}

Associations between history of depression diagnosis before pregnancy from the Care Register for Healthcare (HILMO) (Panel A; $\mathrm{P}=0.37$ for interaction with gestational week at blood sampling) and from self-reports (Panel B; $\mathrm{P}=0.99$ for interaction with gestational week at blood sampling) and probable clinical depression during pregnancy (Panel C; $\mathrm{P}=0.62$ for interaction with gestational week at blood sampling) and high-sensitivity C-reactive protein across the three measurement points during pregnancy.

\section{Figure 2.}

Associations between 1) history of depression diagnosis before pregnancy from the Care Register for Healthcare (HILMO) (Panel A; $\mathrm{P}=0.60$ for interaction with gestational week at blood sampling) and 2) probable clinical depression during pregnancy (Panel $\mathrm{C} ; \mathrm{P}=0.70$ for interaction with gestational week at blood sampling) and glycoprotein acetyls across the three measurement points during pregnancy.

\section{Figure 3.}

Associations between depressive symptoms during pregnancy and high-sensitivity C-reactive protein during pregnancy in women who in early pregnancy were normal weight (body mass index $[\mathrm{BMI}]<$ $25 \mathrm{~kg} / \mathrm{m}^{2}$ ), overweight (BMI $25-29.99 \mathrm{~kg} / \mathrm{m}^{2}$ ) or obese $\left(\mathrm{BMI} \geq 30 \mathrm{~kg} / \mathrm{m}^{2}\right)$. 
Figure 1.

Panel A.

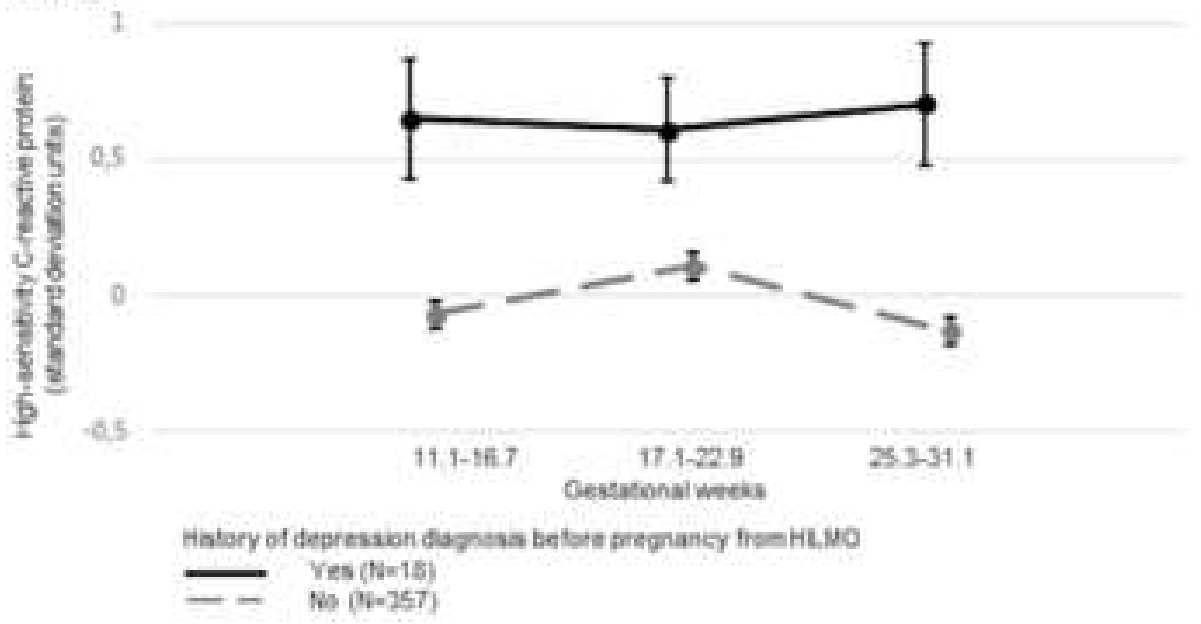

Pasel 8

1
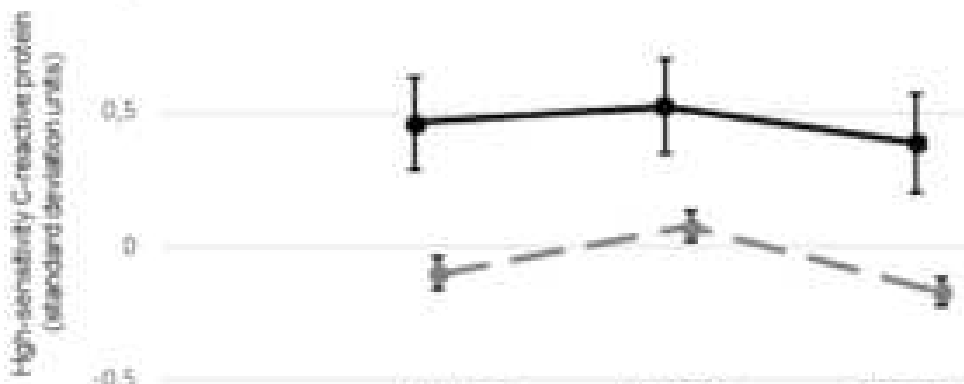

0.5

11 1. 16.7 171229

Cestatonainets

2531.1

Mistory of depression day woss before pregnancy fromseif--ieports

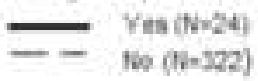

Panet $C$

2
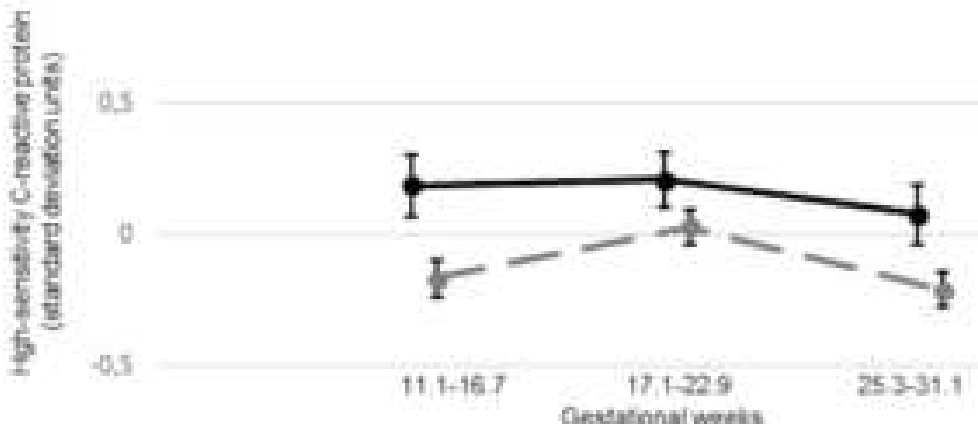

Depressve symetoms durng prephancy

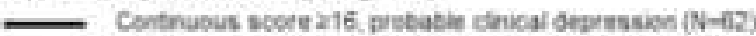

- Contrupus score vie, no probable clinical depressopo (NV229) 
figure 2.

Panel A.

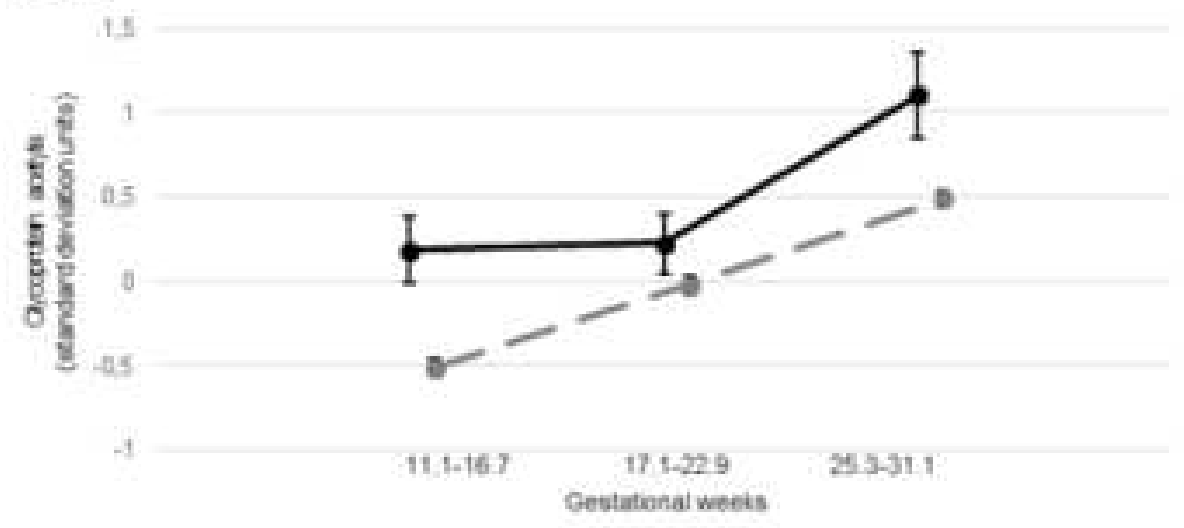

Mialocy of depresson dognosas betore preprancy frem HLWO

- Ves (0iris)

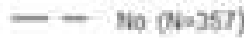

Pane: 8

1 is

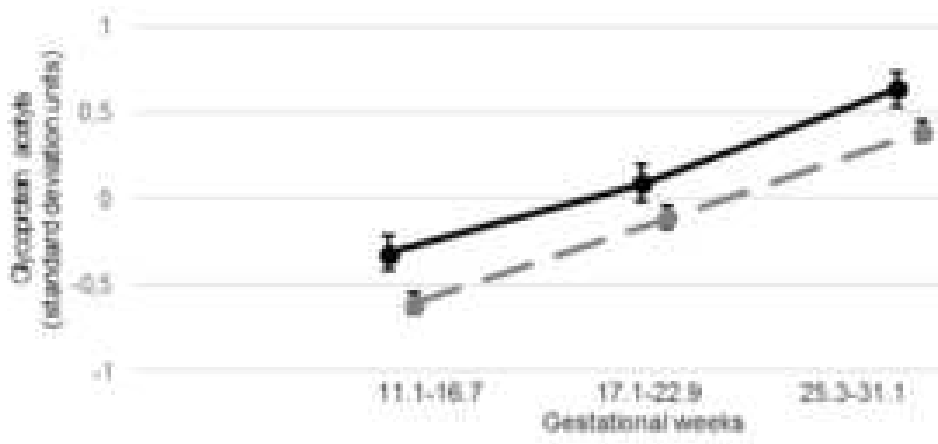

Deprisuve aymetoms durng preshancy

- Contnuous scure 216, probabie chical depressun (12-61)

- Centhuous scorv ste, no probabie cinical deprissen (N-210) 


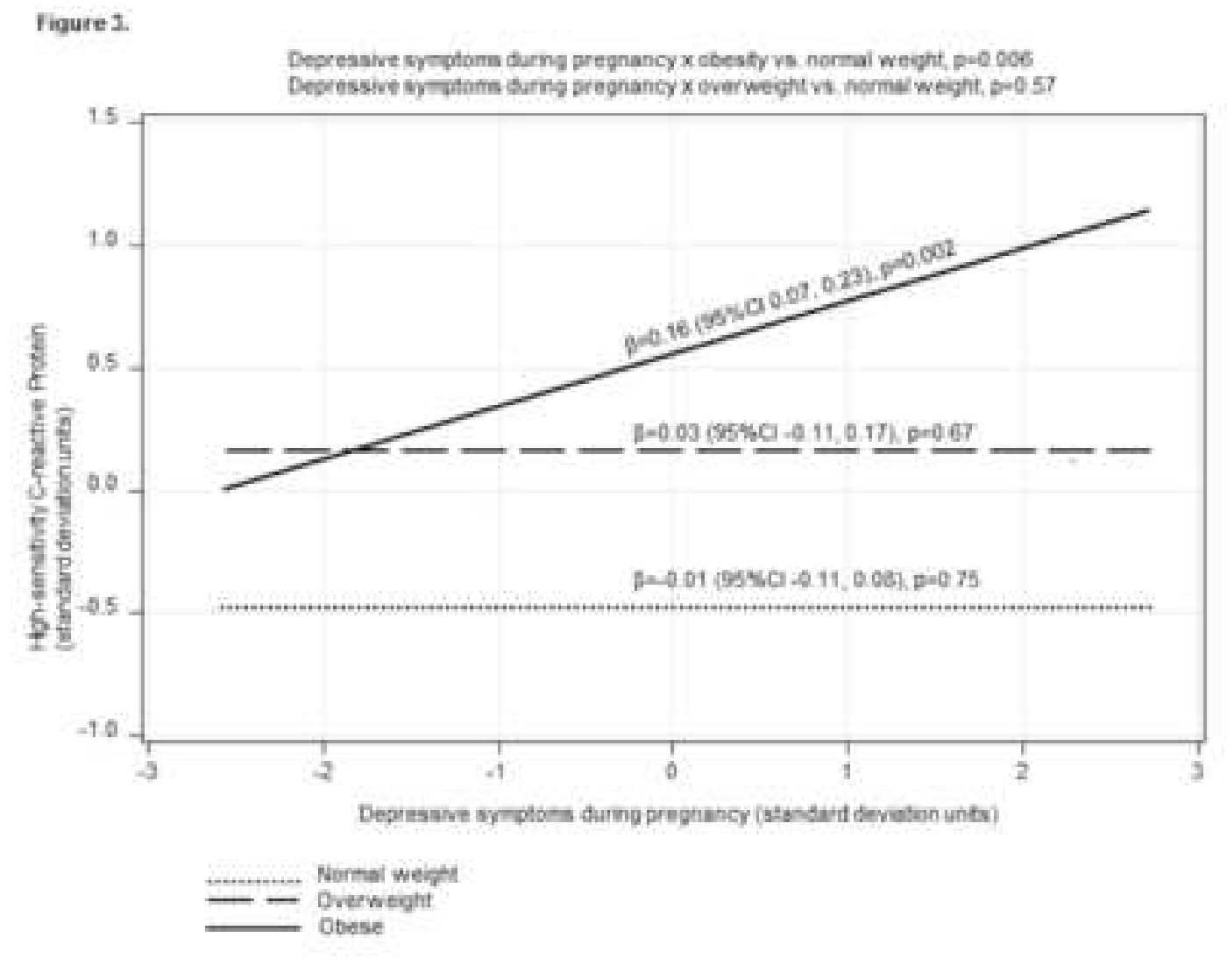

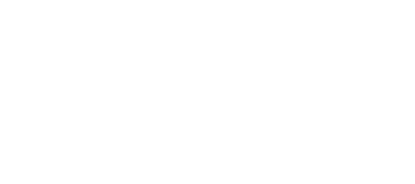




\begin{tabular}{|c|c|c|c|c|c|c|c|c|c|c|c|}
\hline & \multicolumn{2}{|c|}{ Entire sample (N=1079) } & \multicolumn{3}{|c|}{$\begin{array}{l}\text { Sample with } 3 \text { high-sensitivity } \mathrm{C}- \\
\text { reactive protein blood samples and } \\
\text { data on history of depression } \\
\text { diagnosis before pregnancy from } \\
\text { HILMO }(\mathrm{N}=375)\end{array}$} & \multicolumn{3}{|c|}{$\begin{array}{l}\text { Sample with } 3 \text { high-sensitivity } C \text { - } \\
\text { reactive protein blood samples and } \\
\text { data on depression diagnosis before } \\
\text { pregnancy from self-reports }(N=347)\end{array}$} & \multicolumn{3}{|c|}{$\begin{array}{c}\text { Sample with } 3 \text { high-sensitivity C- } \\
\text { reactive protein blood samples and } \\
\text { data on depressive symptoms reported } \\
\text { concurrently to the blood samplings } \\
\text { during pregnancy }(\mathrm{N}=295)\end{array}$} \\
\hline & $\begin{array}{l}\text { Mean/N } \\
(\mathrm{SD} / \%)\end{array}$ & Range & $\begin{array}{l}\text { Mean/N } \\
\text { (SD/\%) }\end{array}$ & Range & P1 & $\begin{array}{l}\text { Mean/N } \\
(\mathrm{SD} / \%)\end{array}$ & Range & $\mathbf{P} 2$ & $\begin{array}{l}\text { Mean/N } \\
(\mathrm{SD} / \%)\end{array}$ & Range & $\mathbf{P 3}$ \\
\hline Age (years) & $33.2(5.8)$ & $17.2-47.4$ & $32.6(5.2)$ & $19.5-47.4$ & 0.14 & $32.6(5.1)$ & $19.5-47.4$ & 0.08 & $32.6(5.1)$ & $20.3-47.4$ & 0.11 \\
\hline$<40$ years, $\mathrm{n}(\%)$ & $902(83.6 \%)$ & & $337(89.9 \%)$ & & 0.003 & $312(89.9 \%)$ & & 0.006 & $265(89.8 \%)$ & & 0.008 \\
\hline$\geq 40$ years, $n(\%)$ & $177(16.4 \%)$ & & $38(10.1 \%)$ & & & $35(10.1 \%)$ & & & $30(10.2 \%)$ & & \\
\hline Data not available, n (\%) & 0 & & 0 & & & 0 & & & 0 & & \\
\hline Education & & & & & 0.71 & & & 0.46 & & & 0.79 \\
\hline Lower secondary or lower & $483(46.1 \%)$ & & $181(48.7 \%)$ & & & $169(48.7 \%)$ & & & $139(47.1 \%)$ & & \\
\hline Upper secondary or tertiary & $564(53.9 \%)$ & & $191(51.3 \%)$ & & & $178(51.3 \%)$ & & & $156(52.9 \%)$ & & \\
\hline Data not available, n (\%) & 32 & & 3 & & & 0 & & & 0 & & \\
\hline Data not available, $\mathrm{n}(\%)$ & 0 & & 0 & & & 0 & & & 0 & & \\
\hline Smoking during pregnancy & & & & & 0.49 & & & 0.46 & & & 0.80 \\
\hline No & $1025(95.4 \%)$ & & $351(93.9 \%)$ & & & $324(93.6 \%)$ & & & $277(94.2 \%)$ & & \\
\hline Quit during first trimester & $39(3.6 \%)$ & & $17(4.6 \%)$ & & & $17(4.9 \%)$ & & & $14(4.8 \%)$ & & \\
\hline Smoked throughout pregnancy & $11(1.0 \%)$ & & $6(1.6 \%)$ & & & $5(1.5 \%)$ & & & $3(1.0 \%)$ & & \\
\hline Data not available, n (\%) & 4 & & 1 & & & 1 & & & 1 & & \\
\hline Alcohol use during pregnancy & & & & & 0.23 & & & 0.30 & & & 0.10 \\
\hline No & $776(71.9 \%)$ & & $295(86.0 \%)$ & & & $285(85.6 \%)$ & & & $252(87.2 \%)$ & & \\
\hline Yes & $158(14.6 \%)$ & & $48(14.0 \%)$ & & & $48(14.4 \%)$ & & & $37(12.8 \%)$ & & \\
\hline Data not available, n (\%) & 145 & & 32 & & & 14 & & & 6 & & \\
\hline $\begin{array}{l}\text { Body Mass Index in early } \\
\text { pregnancy }\left(\mathrm{kg} / \mathrm{m}^{2}\right)\end{array}$ & $27.4(6.5)$ & $17.2-55.0$ & $27.1(6.6)$ & $17.6-55.0$ & 0.44 & $27.1(6.7)$ & $17.6-55.0$ & 0.46 & $26.7(6.7)$ & $17.7-55.0$ & 0.10 \\
\hline Normal weight $\left(<24.99 \mathrm{~kg} / \mathrm{m}^{2}\right)$ & $503(46.6 \%)$ & & $183(48.8 \%)$ & & 0.15 & $171(49.3 \%)$ & & 0.26 & $153(51.9 \%)$ & & 0.08 \\
\hline Overweight $\left(25-29.99 \mathrm{~kg} / \mathrm{m}^{2}\right)$ & $193(17.9 \%)$ & & $78(20.8 \%)$ & & & $69(19.9 \%)$ & & & $58(19.7 \%)$ & & \\
\hline Obese $\left(\geq 30 \mathrm{~kg} / \mathrm{m}^{2}\right)$ & $383(35.5 \%)$ & & $114(30.4 \%)$ & & & $107(30.8 \%)$ & & & $84(28.5 \%)$ & & \\
\hline Data not available, $\mathrm{n}(\%)$ & 0 & & 0 & & & 0 & & & 0 & & \\
\hline $\begin{array}{l}\text { Hypertensive disorders in } \\
\text { pregnancy }\end{array}$ & & & & & 0.87 & & & 0.32 & & & 0.37 \\
\hline Normotension & $705(65.5 \%)$ & & $237(63.2 \%)$ & & & $222(64.1 \%)$ & & & $192(65.1 \%)$ & & \\
\hline
\end{tabular}




\section{Gestational hypertension}

Pre-eclampsia

Chronic hypertension

Data not available, n (\%)

Diabetes disorders in pregnancy

$$
\text { No }
$$

Gestational diabetes

Type 1 diabetes

Data not available, n (\%)

History of depression diagnosis before pregnancy

from HILMO

No
Yes
Data not available, n (\%)

from self-reports

$\begin{array}{ll}\text { No } & 827(89.6 \%) \\ \text { Yes } & 96(10.4 \%) \\ \text { Data not available, n (\%) } & 156\end{array}$

Depressive symptoms

during pregnancy

continuous score (mean of

sampling points)

binary score (continuous

score $\geq 16$, probable clinical

depression)

No
Yes
Data not available, n (\%)

High-sensitivity C-reactive

protein $(\mathrm{mg} / \mathrm{L})$, Median

(Interquartile Range)

First sampling point

(11.1-16.7 gestational weeks)

Data not available, n (\%)

Second sampling point

\section{$1033(96.1 \%)$ \\ $39(3.6 \%)$ \\ $108(10.0 \%)$ \\ $168(15.6 \%)$ \\ $818(75.8 \%)$ $239(22.2 \%)$ \\ $22(2.0 \%)$ \\ 0}

156

$11.61(7.05)$

$609(78.9 \%)$

307

3.81 669
$0.5-44.7$

$11.51(7.11)$

$0.3-45.0$

0.72

0.80 $163(21.1 \%)$

$4.53(2.42-8.69) \quad 0.31-60.65 \quad 4.56(2.37-8.95) \quad 0.31-60.65 \quad 0.83$

0.66

0.81

0.04

$229(78.7 \%)$

$62(21.3 \%)$

84
$34(9.8 \%)$

$33(9.5 \%)$

$58(16.7 \%)$

0

$268(77.2 \%)$

72 (20.8)

7 (2.0\%)

0

$329(95.1 \%)$

$17(4.9 \%)$

1

$324(93.4 \%)$

$23(6.6 \%)$

0

$11.54(7.15)$

$0.33-45.0$

0.76

$10.58(10.5)$

$0.33-45.0$

0.78

0.99

0.87

$221(78.9 \%)$

$59(21.1 \%)$

67

$231(78.3 \%)$

$64(21.7 \%)$

0

0

$(6.8 \%)$

15

$3.80(2.12-7.11) \quad 0.23-31.49 \quad 0.90$

0

$4.30(2.30-7.97) \quad 0.31-60.65 \quad 0.48$ 
(17.1-22.9 gestational weeks)

Data not available, n (\%)

674

0

Third sampling point

(25.3-31.1 gestational weeks)

Data not available, n $(\%)$

Glycoprotein acetyls (mmol/l)*

First sampling point

(11.1-16.7 gestational weeks)

Data not available, n (\%)

Second sampling point

(17.1-22.9 gestational weeks)

Data not available, n (\%)

Third sampling point

(25.3-31.1 gestational weeks)

Data not available, n (\%)

$1.26(0.16)$

$1.34(0.18)$

679
$677 \quad 0 \quad 0$

$0.89-1.85 \quad 1.27(0.16)$

$0.89-1.85$

$0.40 \quad 1.26(0.16)$

31

0.94-2.14 $1.35(0.17)$

$1.0-2.14$

$0.44 \quad 1.35(0.17)$

31

31

$1.06-2.25 \quad 1.45(0.18)$

$1.06-2.25 \quad 1.0 \quad 1.44(0.17)$

31

31
0

$3.72(1.98-6.37) \quad 0.22-26.10$

0.39

0

$.25(0.15)$

0.42
$1.0-2.14$

24

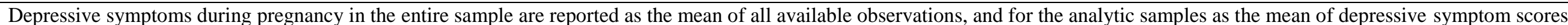
measured at the time of the three blood samplings during pregnancy.

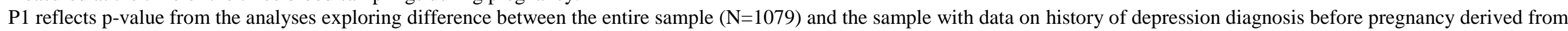

HILMO $(\mathrm{N}=375)$

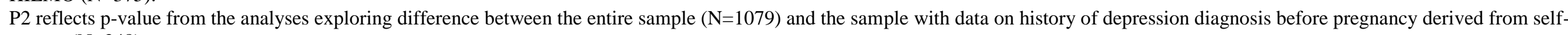
reports $(\mathrm{N}=348)$.

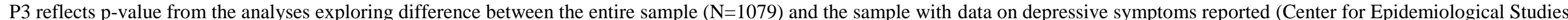
Depression Scale) at the time of the three blood samplings during pregnancy $(\mathrm{N}=295)$.

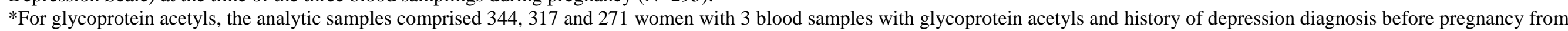

HILMO and from self-reports and depressive symptoms reported concurrent to the blood samplings during pregnancy, respectively.

HILMO refers to Care Register for Healthcare. 
Table 2. Associations of a history of depression diagnosis before pregnancy derived from the Care Register for Healthcare (HILMO) and self-reports, and depressive symptoms and probable clinical depression reported during pregnancy with high sensitivity C-Reactive protein and glycoprotein acetyls across the three measurement points during pregnancy.

\begin{tabular}{|c|c|c|c|c|c|c|c|c|c|}
\hline & \multicolumn{3}{|c|}{ Model 1} & \multicolumn{3}{|c|}{ Model 2} & \multicolumn{3}{|c|}{ Model 3} \\
\hline & $\begin{array}{l}\text { Estimate in } \\
\text { SD units* }\end{array}$ & $95 \% \mathrm{CI}$ & $\mathrm{P}$ & $\begin{array}{l}\text { Estimate in } \\
\text { SD units* }\end{array}$ & $95 \% \mathrm{CI}$ & $\mathrm{P}$ & $\begin{array}{l}\text { Estimate in } \\
\text { SD units* }\end{array}$ & $95 \% \mathrm{CI}$ & $\mathrm{P}$ \\
\hline \multicolumn{10}{|c|}{ High-sensitivity C-reactive protein (SD units) (outcome) } \\
\hline \multicolumn{10}{|l|}{ History of depression diagnosis } \\
\hline from HILMO & 0.69 & $0.26,1.11$ & 0.002 & 0.50 & $0.08,0.92$ & 0.02 & 0.16 & $-0.21,0.53$ & 0.40 \\
\hline from self-reports & 0.56 & $0.17,0.94$ & 0.005 & 0.47 & $0.10,0.85$ & 0.01 & 0.28 & $-0.05,0.60$ & 0.09 \\
\hline \multicolumn{10}{|l|}{$\begin{array}{l}\text { Depressive symptoms } \\
\text { during pregnancy }\end{array}$} \\
\hline continuous score (SD units) & 0.06 & $0.00,0.13$ & 0.05 & 0.06 & $0.00,0.13$ & 0.05 & 0.05 & $-0.01,0.11$ & 0.14 \\
\hline $\begin{array}{l}\text { binary score (continuous } \\
\text { score } \geq 16 \text {, probable clinical } \\
\text { depression vs. continuous } \\
\text { score }<16, \text { no probable clinical } \\
\text { depression) }\end{array}$ & 0.28 & $0.03,0.53$ & 0.03 & 0.28 & $0.04,0.52$ & 0.02 & 0.20 & $-0.01,0.42$ & 0.06 \\
\hline \multicolumn{10}{|c|}{ Glycoprotein acetyls (SD units) (outcome) } \\
\hline \multicolumn{10}{|l|}{$\begin{array}{l}\text { History of depression diagnosis } \\
\text { before pregnancy (yes vs. no) }\end{array}$} \\
\hline from HILMO & 0.52 & $0.12,0.93$ & 0.01 & 0.42 & $0.01,0.84$ & 0.04 & 0.04 & $-0.32,0.39$ & 0.84 \\
\hline from self-reports & 0.30 & $-0.06,0.66$ & 0.10 & 0.24 & $-0.11,0.60$ & 0.18 & 0.04 & $-0.26,0.34$ & 0.78 \\
\hline \multicolumn{10}{|l|}{$\begin{array}{l}\text { Depressive symptoms } \\
\text { during pregnancy }\end{array}$} \\
\hline $\begin{array}{l}\text { continuous score (SD units) } \\
\text { binary score (continuous }\end{array}$ & 0.05 & $-0.01,0.11$ & 0.10 & 0.05 & $-0.01,0.11$ & 0.10 & 0.04 & $-0.02,0.09$ & 0.23 \\
\hline $\begin{array}{l}\text { score } \geq 16 \text {, probable clinical } \\
\text { depression vs. continuous } \\
\text { score }<16 \text {, no probable clinical } \\
\text { depression) }\end{array}$ & 0.25 & $0.02,0.46$ & 0.04 & 0.25 & $0.02,0.48$ & 0.03 & 0.19 & $-0.008,0.38$ & 0.06 \\
\hline \multicolumn{10}{|c|}{$\begin{array}{l}\text { Note. *Estimates and 95\% Confidence Intervals (95\% CI) reflect differences between those with and without a history of depression diagnosis before pregnancy or with and } \\
\text { without probable clinical depression during pregnancy in high-sensitivity C-reactive protein (hsCRP) and glycoprotein acetyls in standard deviation (SD) units or change in SD } \\
\text { units in hsCRP and glycoprotein acetyls per SD unit change in the continuous depressive symptom scores during pregnancy. } \\
\text { Model } 1 \text { is unadjusted for covariates but includes the gestational week when blood was sampled as a within-person time-varying predictor, Model } 2 \text { is Model } 1+\text { age and } \\
\text { education, Model } 3 \text { is Model } 2+\text { body mass index in early pregnancy (categorized as normal weight }\left[<25 \mathrm{~kg} / \mathrm{m}^{2}\right], \text { overweight }\left[25-29.99 \mathrm{~kg} / \mathrm{m}^{2}\right] \text { and obese }\left[\geq 30 \mathrm{~kg} / \mathrm{m}^{2}\right] \text { ). }\end{array}$} \\
\hline
\end{tabular}




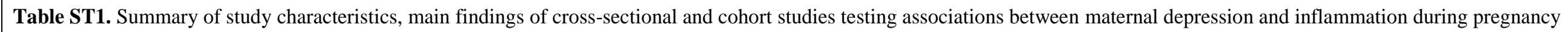
and the quality of evidence according to the Newcastle-Ottava Scale criteria.

\begin{tabular}{|c|c|c|c|c|c|c|c|c|c|c|c|c|c|}
\hline \multirow{2}{*}{ Study } & \multirow{2}{*}{ Population } & \multirow{2}{*}{$\begin{array}{c}\text { Sample } \\
\text { Size }\end{array}$} & \multirow{2}{*}{$\begin{array}{l}\text { Study } \\
\text { Design }\end{array}$} & \multirow{2}{*}{$\begin{array}{c}\text { Depression } \\
\text { Measure }\end{array}$} & \multirow{2}{*}{$\begin{array}{l}\text { Time of } \\
\text { Depression } \\
\text { Measure }\end{array}$} & \multirow{2}{*}{$\begin{array}{l}\text { Inflam- } \\
\text { mation } \\
\text { Markers }\end{array}$} & \multirow{2}{*}{$\begin{array}{l}\text { Time of } \\
\text { Inflamma- } \\
\text { tion } \\
\text { Measure }\end{array}$} & \multirow{2}{*}{$\begin{array}{l}\text { Important } \\
\text { Covari- } \\
\text { ates }\end{array}$} & \multirow{2}{*}{ Results } & \multicolumn{4}{|c|}{ Quality of evidence } \\
\hline & & & & & & & & & & Selection & Comparability & Outcome & Overall $^{1}$ \\
\hline \multicolumn{14}{|c|}{ CROSS-SECTIONAL STUDIES: } \\
\hline 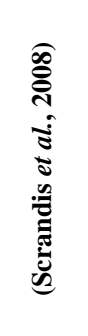 & $\begin{array}{l}\text { Women } \\
\text { from two } \\
\text { Mid- } \\
\text { Atlantic } \\
\text { obstetric } \\
\text { clinics and } \\
\text { one } \\
\text { birthing } \\
\text { center, } \\
\text { USA }\end{array}$ & 27 & $\begin{array}{c}\text { Cross- } \\
\text { sectional }\end{array}$ & SIGH-SAD ${ }^{2}$ & $35-38 \mathrm{gw}^{3}$ & $\begin{array}{l}\text { IL- }^{4} \\
\text { CRP }^{5}\end{array}$ & $35-38 \mathrm{gw}^{3}$ & None & $\begin{array}{l}\text { Higher depressive symptoms } \\
\text { were significantly correlated with } \\
\text { higher CRP, but not IL-6 }\end{array}$ & $3 / 5$ & $0 / 2$ & $1 / 3$ & Poor \\
\hline 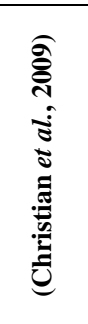 & $\begin{array}{c}\text { Women } \\
\text { with low } \\
\text { socioeco- } \\
\text { nomic } \\
\text { status from } \\
\text { Ohio State } \\
\text { University } \\
\text { Prenatal } \\
\text { Clinic, } \\
\text { USA }\end{array}$ & 60 & $\begin{array}{c}\text { Cross- } \\
\text { sectional }\end{array}$ & CES-D ${ }^{6}$ & $\begin{array}{c}\text { Mean }=15 \\
\mathrm{SD}=4.8 \\
\mathrm{gw}^{3}\end{array}$ & $\begin{array}{c}\text { IL-6 }{ }^{4} \\
\text { TNF- } \alpha^{7}\end{array}$ & $\begin{array}{c}\text { Mean }=15 \\
\mathrm{SD}=4.8 \mathrm{gw}^{3}\end{array}$ & $\begin{array}{l}\text { Body Mass } \\
\text { Index }\end{array}$ & $\begin{array}{l}\text { Higher depressive symptoms } \\
\text { were significantly associated with } \\
\text { higher IL- } 6 \text { but not TNF- } \alpha \text {. }\end{array}$ & $2 / 5$ & $1 / 2$ & $3 / 3$ & Fair \\
\hline 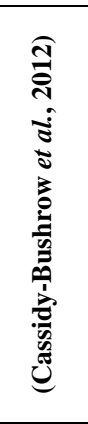 & $\begin{array}{c}\text { African } \\
\text { American } \\
\text { women } \\
\text { from the } \\
\text { Henry Ford } \\
\text { Health } \\
\text { System } \\
\text { Clinics, } \\
\text { Detroit } \\
\text { area, USA }\end{array}$ & 187 & $\begin{array}{c}\text { Cross- } \\
\text { sectional }\end{array}$ & CES-D ${ }^{6}$ & $\begin{array}{c}13.1-28.6 \\
\mathrm{gw}^{3}\end{array}$ & $\begin{array}{c}\text { IL-6 }{ }^{4} \\
\text { IL-1 } \beta^{4} \\
\text { IL-10 } \\
\text { hs-CRP } \\
\text { TNF- } \alpha^{7}\end{array}$ & $\begin{array}{c}13.1-28.6 \\
\mathrm{gw}^{3}\end{array}$ & $\begin{array}{l}\text { Body Mass } \\
\text { Index }\end{array}$ & $\begin{array}{l}\text { Higher depressive symptoms } \\
\text { were significantly associated with } \\
\text { higher IL-1 } 1 \beta \text { but not with hsCRP, } \\
\text { IL-6 or TNF- } \alpha \text { levels. Body } \\
\text { Mass Index moderated the } \\
\text { associations: higher depressive } \\
\text { symptoms were associated with } \\
\text { higher IL-6 and IL-10 in women } \\
\text { with lower Body Mass Index, } \\
\text { while higher depressive } \\
\text { symptoms were associated with } \\
\text { lower IL-10 in women with } \\
\text { higher Body Mass Index. }\end{array}$ & $3 / 5$ & $2 / 2$ & $3 / 3$ & Fair \\
\hline 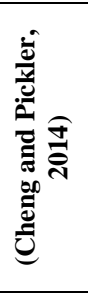 & $\begin{array}{c}\text { Women } \\
\text { from a } \\
\text { prenatal } \\
\text { clinic of a } \\
\text { large, urban } \\
\text { medical } \\
\text { center, } \\
\text { Ohio area, } \\
\text { USA }\end{array}$ & 12 & $\begin{array}{c}\text { Cross- } \\
\text { sectional* }\end{array}$ & CES-D ${ }^{6}$ & $\geq 36 \mathrm{gw}^{3}$ & $\begin{array}{c}\text { IL-1 }^{4}{ }^{4} \\
\text { IL-5 }^{4} \\
\text { IL-7 }^{4} \\
\text { TNF- } \alpha^{7} \\
\text { MIP-1 } \beta^{8} \\
\text { VEGF }^{9} \\
\text { MCP-1 }^{10} \\
\text { G-CSF }^{11}\end{array}$ & $\geq 36 \mathrm{gw}^{3}$ & None & $\begin{array}{l}\text { Higher depressive symptoms } \\
\text { were associated with higher } \\
\text { MIP-1 } 1 \beta \text {, but not with TNF- } \alpha \text {, IL- } \\
\text { 1 } \beta \text {, IL-5, IL-7, VEGF, MCP-1 or } \\
\text { G-CSF. }\end{array}$ & $1 / 5$ & $0 / 2$ & $1 / 3$ & Poor \\
\hline
\end{tabular}




\begin{tabular}{|c|c|c|c|c|c|c|c|c|c|c|c|c|c|}
\hline 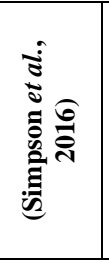 & $\begin{array}{c}\text { Women } \\
\text { from } \\
\text { Women's } \\
\text { Health } \\
\text { Concerns } \\
\text { Clinic, } \\
\text { Ontario, } \\
\text { Canada } \\
\end{array}$ & 33 & $\begin{array}{c}\text { Cross- } \\
\text { sectional* }\end{array}$ & EPDS $^{12}$ & $\geq 26 \mathrm{gw}^{3}$ & $\begin{array}{c}\text { IL-6 }^{4} \\
\text { IL- }^{4} 0^{4} \\
\text { CRP }^{5} \\
\text { TNF- } \alpha^{7}\end{array}$ & $\geq 26 \mathrm{gw}^{3}$ & $\begin{array}{l}\text { Body Mass } \\
\text { Index; } \\
\text { Exclusion } \\
\text { criteria: } \\
\text { hyperten- } \\
\text { sive } \\
\text { disorders, } \\
\text { diabetes } \\
\end{array}$ & $\begin{array}{l}\text { No significant associations } \\
\text { between depressive symptoms } \\
\text { and CRP, IL-6, TNF- } \alpha \text { or IL-10. }\end{array}$ & $2 / 5$ & $2 / 2$ & $2 / 3$ & Fair \\
\hline \multicolumn{14}{|c|}{ COHORT STUDIES: } \\
\hline 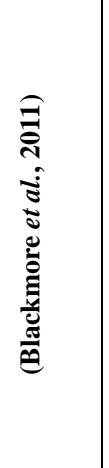 & $\begin{array}{c}\text { Women at } \\
\text { low to } \\
\text { medium } \\
\text { obstetric } \\
\text { risk from } \\
\text { the } \\
\text { University } \\
\text { of } \\
\text { Rochester } \\
\text { Clinical } \\
\text { Research } \\
\text { Center, } \\
\text { New York, } \\
\text { USA }\end{array}$ & $\begin{array}{l}130 \text { for } \\
\text { IL- } 6^{4} \text {, } \\
137 \text { for } \\
\text { TNF- } \alpha^{7}\end{array}$ & Cohort & $\begin{array}{c}\mathrm{SCID}^{13} \\
\text { diagnosis of } \\
\text { major } \\
\text { depressive } \\
\text { disorder } \\
\text { EPDS }^{12}\end{array}$ & $\begin{array}{c}18 \text { and } 32 \\
\mathrm{gw}^{3}\end{array}$ & $\begin{array}{l}\text { IL-6 }{ }^{4} \\
\text { TNF- } \alpha^{7}\end{array}$ & $\begin{array}{c}18 \text { and } 32 \\
\mathrm{gw}^{3}\end{array}$ & $\begin{array}{l}\text { Body Mass } \\
\text { Index }\end{array}$ & $\begin{array}{l}\text { No significant associations of } \\
\text { depression diagnosis or } \\
\text { depressive symptoms with IL-6 } \\
\text { or TNF- } \alpha \text { at either measurement } \\
\text { point. }\end{array}$ & $4 / 4$ & $1 / 2$ & $3 / 3$ & Good \\
\hline 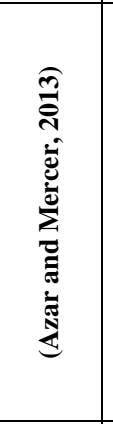 & $\begin{array}{c}\text { Caucasian } \\
\text { women, } \\
\text { low to } \\
\text { medium } \\
\text { socioeco- } \\
\text { nomic } \\
\text { status from } \\
\text { Cumber- } \\
\text { land } \\
\text { Regional } \\
\text { Health Care } \\
\text { Center, } \\
\text { Canada } \\
\end{array}$ & 27 & Cohort & PHQ-9 $9^{14}$ & $\begin{array}{l}7-10 \text { and } \\
16-20 \mathrm{gw}^{3}\end{array}$ & $\begin{array}{l}\text { IL- }^{4} \\
\text { CRP }^{5} \\
\text { TNF- } \alpha^{7}\end{array}$ & $\begin{array}{l}7-10 \text { and } \\
16-20 \mathrm{gw}^{3}\end{array}$ & $\begin{array}{l}\text { Exclusion } \\
\text { criteria: } \\
\text { hyperten- } \\
\text { sive } \\
\text { disorders }\end{array}$ & $\begin{array}{l}\text { Higher depressive symptoms in } \\
\text { early pregnancy were associated } \\
\text { with higher CRP and TNF- } \alpha \text { in } \\
\text { early and mid-pregnancy and } \\
\text { with higher IL-6 in mid- } \\
\text { pregnancy. An increase in } \\
\text { depressive symptoms from early } \\
\text { to mid-pregnancy was also } \\
\text { associated with higher IL-6 in } \\
\text { mid-pregnancy. }\end{array}$ & $1 / 4$ & $0 / 2$ & $3 / 3$ & Poor \\
\hline 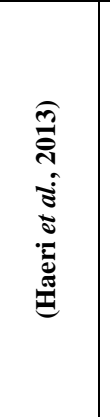 & $\begin{array}{c}\text { Women } \\
\text { from } \\
\text { Perinatal } \\
\text { Mood } \\
\text { Disorders } \\
\text { Clinic and } \\
\text { who } \\
\text { delivered at } \\
\text { a single } \\
\text { tertiary } \\
\text { hospital, } \\
\text { Texas, } \\
\text { USA }\end{array}$ & 200 & Cohort & $\begin{array}{l}\text { Major } \\
\text { Depressive } \\
\text { Disorder } \\
\text { diagnosis } \\
\text { EPDS }^{12}\end{array}$ & $\begin{array}{c}\text { Major } \\
\text { Depressive } \\
\text { Disorder } \\
\text { diagnosis } \\
\text { during } \\
\text { pregnancy } \\
\text { EPDS }{ }^{11}: \\
12.7 \mathrm{gw}^{3}\end{array}$ & $\begin{array}{l}\text { IL-6 }{ }^{4} \\
\text { TNF- } \alpha^{7}\end{array}$ & $11-14 \mathrm{gw}^{3}$ & $\begin{array}{l}\text { Body Mass } \\
\text { Index, } \\
\text { Exclusion } \\
\text { criteria: } \\
\text { hyperten- } \\
\text { sive } \\
\text { disorders, } \\
\text { diabetes, } \\
\text { infections }\end{array}$ & $\begin{array}{l}\text { Women with depression diagnosis } \\
\text { had higher TNF- } \alpha \text { and IL- } 6 \text { levels } \\
\text { than controls with no depression } \\
\text { as indicated by EPDS. }\end{array}$ & $2 / 4$ & $2 / 2$ & $2 / 3$ & Fair \\
\hline 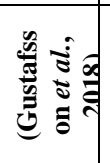 & $\begin{array}{l}\text { Women } \\
\text { with } \\
\text { familial or } \\
\text { personal } \\
\text { history of }\end{array}$ & 68 & Cohort & CES-D ${ }^{6}$ & $\begin{array}{c}24 \text { and } 37 \\
\mathrm{gw}^{3}\end{array}$ & $\begin{array}{c}\text { IL- } 6^{4} \\
\text { TNF- } \alpha^{7} \\
\text { MCP- } 1^{10} \text { and } \\
\text { a latent } \\
\text { variable }\end{array}$ & $37 \mathrm{gw}^{3}$ & $\begin{array}{l}\text { Exclusion } \\
\text { criteria: } \\
\text { high-risk or } \\
\text { medically } \\
\text { compli- }\end{array}$ & $\begin{array}{l}\text { Higher depressive symptoms } \\
\text { were associated with higher IL-6 } \\
\text { and TNF- } \alpha \text {, but not with MCP-1. } \\
\text { Higher depressive symptoms } \\
\text { were also associated with the }\end{array}$ & $0 / 4$ & $0 / 2$ & $2 / 3$ & Poor \\
\hline
\end{tabular}




\begin{tabular}{|c|c|c|c|c|c|c|c|c|c|c|c|c|c|}
\hline & $\begin{array}{l}\text { ADHD } \\
\text { from large } \\
\text { hospital } \\
\text { clinic, } \\
\text { Oregon, } \\
\text { USA }\end{array}$ & & & & & $\begin{array}{l}\text { combining all } \\
\text { three markers }\end{array}$ & & $\begin{array}{c}\text { cated } \\
\text { pregnancy }\end{array}$ & $\begin{array}{c}\text { latent antenatal inflammation } \\
\text { variable. }\end{array}$ & & & & \\
\hline 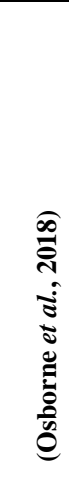 & 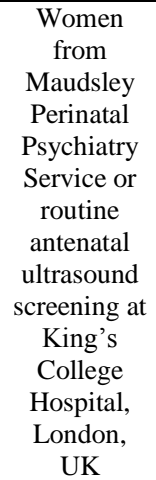 & 106 & Cohort & $\begin{array}{c}\mathrm{SCID}^{13} \\
\text { diagnosis of } \\
\text { major } \\
\text { depressive } \\
\text { disorder } \\
\text { BDI }^{15}\end{array}$ & $\begin{array}{c}\text { major } \\
\text { depressive } \\
\text { disorder } \\
\text { diagnosis } \\
25 \mathrm{gw}^{3} \\
\text { BDI } 32 \\
\text { gw }^{3}\end{array}$ & $\begin{array}{c}\text { IL-2 }^{4} \\
\text { IL- }^{4} \\
\text { IL-6 }^{4} \\
\text { IL-1 } \\
\text { IL-1 }{ }^{4} \\
\text { hs-CRP } \\
\text { TNF- } \alpha^{7} \\
\text { VEGF }^{9} \\
\text { MCP-1 } \\
\text { EGF }^{16}\end{array}$ & $23.9-34.9 \mathrm{gw}^{3}$ & $\begin{array}{l}\text { Body Mass } \\
\text { Index, } \\
\text { exclusion } \\
\text { criteria: } \\
\text { gestational } \\
\text { diabetes, } \\
\text { hyperten- } \\
\text { sion }\end{array}$ & $\begin{array}{l}\text { Women with major depressive } \\
\text { disorder had higher IL-6, IL-10, } \\
\text { TNF- } \alpha \text { and VEGF, but no } \\
\text { differences in IL-2, IL-1 } \beta \text {, } \\
\text { hsCRP, TNF- } \alpha, \text { MCP-1 or EGF. }\end{array}$ & $2 / 4$ & $2 / 2$ & $2 / 3$ & Fair \\
\hline \multicolumn{14}{|c|}{ 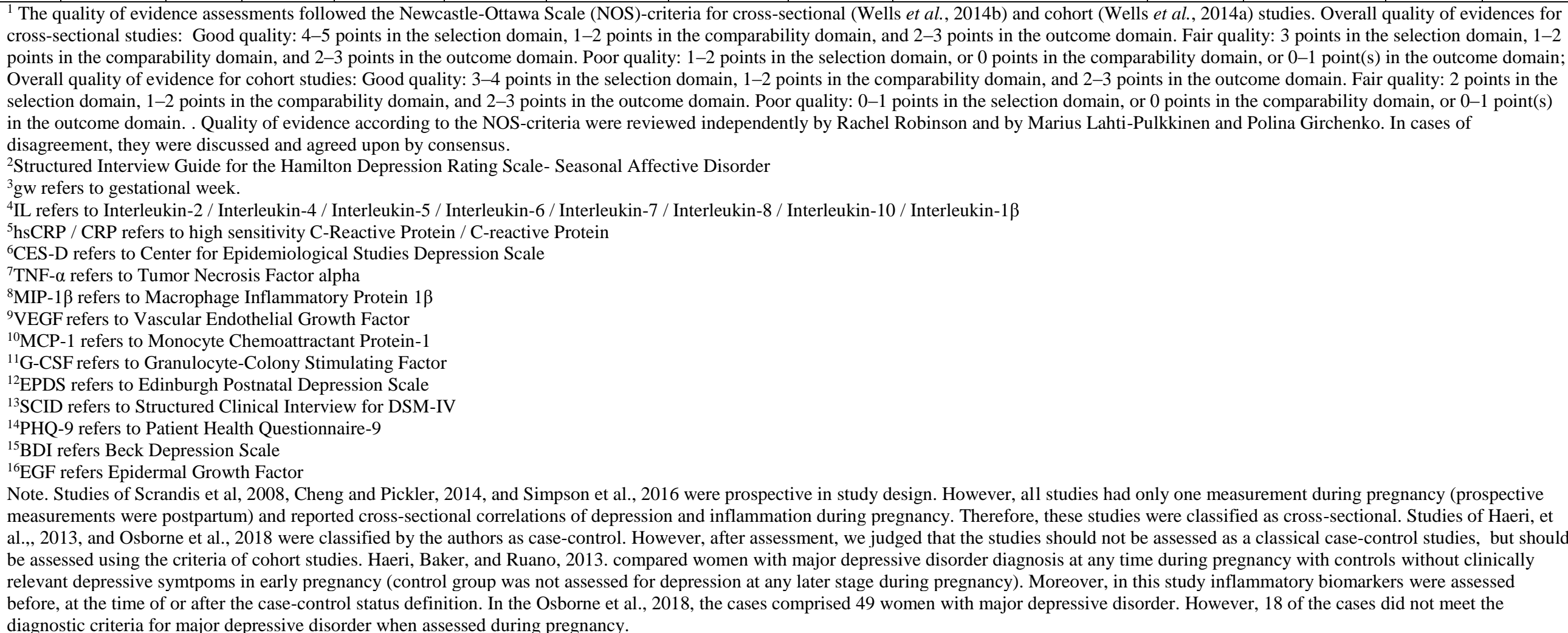 } \\
\hline
\end{tabular}




\section{REFERENCES}

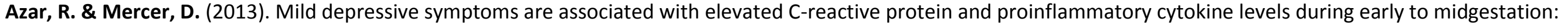
a prospective pilot study. Journal of Women's Health, 22, 385-389.

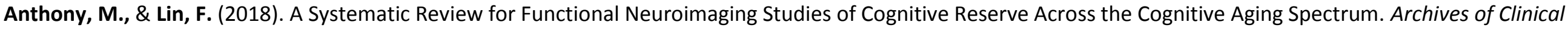
Neuropsychology 33, 937-948.

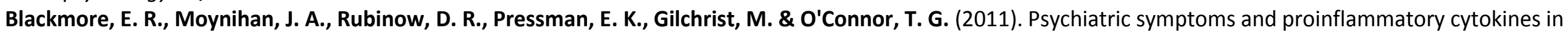
pregnancy. Psychosomatic Medicine, 73, 656-663.

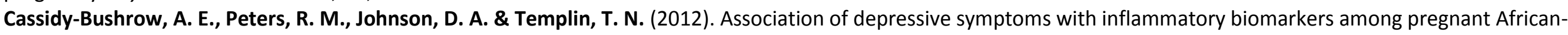
American women. Journal of Reproductive Immunology, 94, 202-209.

Cheng, C. Y. \& Pickler, R. H. (2014). Perinatal stress, fatigue, depressive symptoms, and immune modulation in late pregnancy and one month postpartum.

ScientificWorldJournal 2014, 652630.

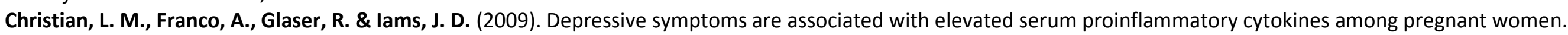
Brain, Behavior, and Immunity, 23, 750-754.

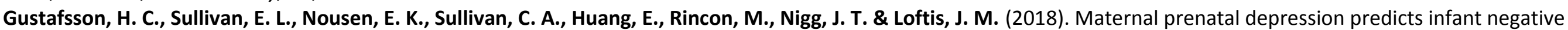
affect via maternal inflammatory cytokine levels. Brain, Behavior, and Immunity, 73, 470-481.

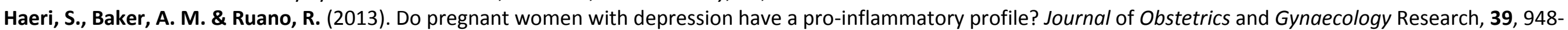
952.

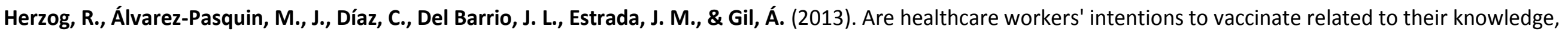
beliefs and attitudes? A systematic review. BMC Public Health 13, 154.

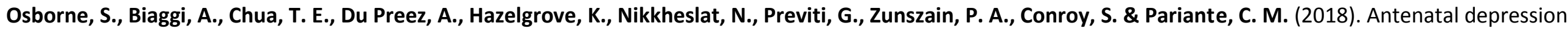

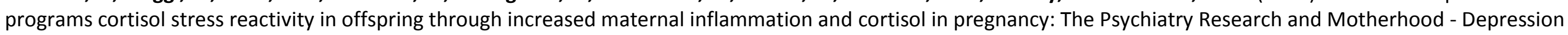
(PRAM-D) Study. Psychoneuroendocrinology, 98, 211-236.

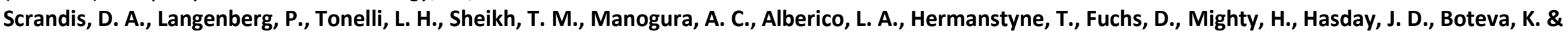

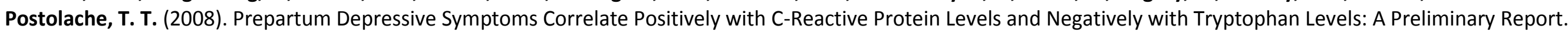
International Journal of Child Health and Human Development : IJCHD, 1, 167-174.

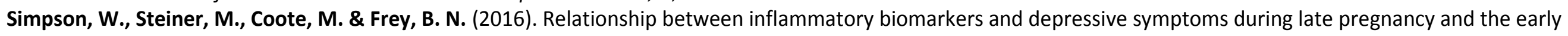
postpartum period: a longitudinal study. Brazilian Journal of Psychiatry, 38, 190-196.

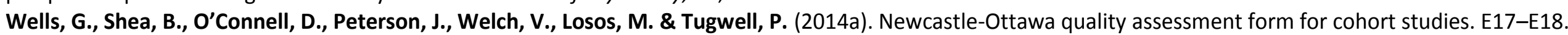
http://www.ncbi.nlm.nih.gov/books/NBK115843/bin/appe-fm3.pdf

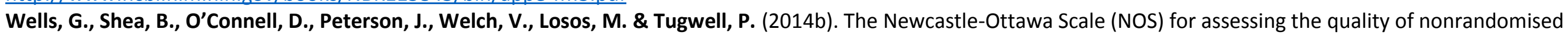
studies in meta-analyses. http://www.ohri.ca/programs/clinical epidemiology/oxford.asp. 
Table ST2. Newcastle-Ottawa scale for assessment of quality of cross-sectional studies (each asterisk represents if individual criterion within the subsection was fulfilled) testing associations between depression and inflammation during pregnancy.

\begin{tabular}{|c|c|c|c|c|c|c|}
\hline Quality assessment criteria & Acceptable $(\star)$ & $\begin{array}{l}\text { Scrandis et al., } \\
2008^{*}\end{array}$ & $\begin{array}{l}\text { Christian et al., } \\
2009\end{array}$ & $\begin{array}{c}\text { Cassidy- } \\
\text { Bushrow et al., } \\
2012\end{array}$ & $\begin{array}{c}\text { Cheng and } \\
\text { Pickler, 2014* }\end{array}$ & $\begin{array}{c}\text { Simpson et al., } \\
2016^{*}\end{array}$ \\
\hline
\end{tabular}

\section{Selection}

Representativeness of the

sample?

Selected group of users

Sample size

Diagnose

\section{Comparability}

Comparability of cohorts on the basis of the design or analysis Study controls for additional risk factors?

\section{Outcome}

Assessment of the Method

Statistical Test
Representative of average pregnant women, (age/being at risk of disease, generalizability, random or non-random sampling)

\section{No inflammatory disease}

Justified and Satisfactory

Structured Interview Depression Diagnosis Health Record Diagnosis or Validated Symptom

Scale $\star$

Study controls for body mass index

Study Controls for hypertensive disorders and/or diabetes disorders

\section{Validated Inflamation Assessment $\star \star$}

Non-validated, clearly defined inflammation assessment $\star$

The statistical assessment is clearly described, provides measurement error, confidence interval and probability level

Overall quality score $($ maximum $=10)$

6

2

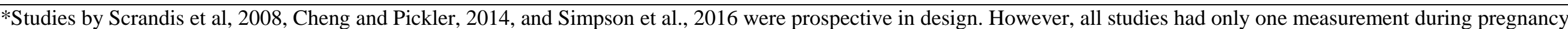

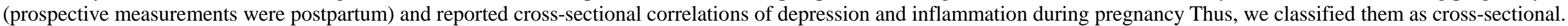

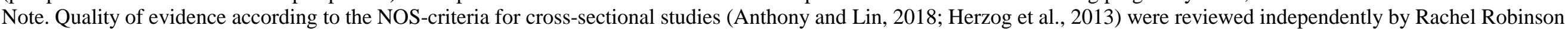
and by Marius Lahti-Pulkkinen and Polina Girchenko. In cases of disagreement, they were discussed and agreed upon by consensus. 


\section{REFERENCES}

Azar, R. \& Mercer, D. (2013). Mild depressive symptoms are associated with elevated C-reactive protein and proinflammatory cytokine levels during early to midgestation: a prospective pilot study. Journal of Women's Health, 22, 385-389.

Cassidy-Bushrow, A. E., Peters, R. M., Johnson, D. A. \& Templin, T. N. (2012). Association of depressive symptoms with inflammatory biomarkers among pregnant AfricanAmerican women. Journal of Reproductive Immunology 94, 202-209.

Cheng, C. Y. \& Pickler, R. H. (2014). Perinatal stress, fatigue, depressive symptoms, and immune modulation in late pregnancy and one month postpartum.

ScientificWorldJournal 2014, 652630.

Christian, L. M., Franco, A., Glaser, R. \& lams, J. D. (2009). Depressive symptoms are associated with elevated serum proinflammatory cytokines among pregnant women. Brain, Behavior, and Immunity, 23, 750-754.

Herzog, R., Álvarez-Pasquin, M., J., Díaz, C., Del Barrio, J. L., Estrada, J. M., \& Gil, Á. (2013). Are healthcare workers' intentions to vaccinate related to their knowledge, beliefs and attitudes? A systematic review. BMC Public Health 13, 154.

Scrandis, D. A., Langenberg, P., Tonelli, L. H., Sheikh, T. M., Manogura, A. C., Alberico, L. A., Hermanstyne, T., Fuchs, D., Mighty, H., Hasday, J. D., Boteva, K. \&

Postolache, T. T. (2008). Prepartum Depressive Symptoms Correlate Positively with C-Reactive Protein Levels and Negatively with Tryptophan Levels: A Preliminary Report. International Journal of Child Health and Human Development; IJCHD, 1, 167-174.

Simpson, W., Steiner, M., Coote, M. \& Frey, B. N. (2016). Relationship between inflammatory biomarkers and depressive symptoms during late pregnancy and the early postpartum period: a longitudinal study. Brazilian Journal of Psychiatry, 38, 190-196. 
Table ST3. Newcastle-Ottawa scale for assessment of quality of cohort studies (each asterisk represents if individual criterion within the subsection was fulfilled) testing associations between maternal depression and inflammation during pregnancy.

\begin{tabular}{|c|c|c|c|c|c|c|}
\hline Quality assessment criteria & Acceptable $(\star)$ & $\begin{array}{c}\text { Blackmore et } \\
\text { al., } 2011\end{array}$ & $\begin{array}{c}\text { Azar and } \\
\text { Mercer, } 2013\end{array}$ & $\begin{array}{c}\text { Haeri et al, } \\
2013^{*}\end{array}$ & $\begin{array}{c}\text { Gustafsson et } \\
\text { al., } \\
2018 \\
\end{array}$ & $\begin{array}{c}\text { Osborne et al., } \\
2018^{*}\end{array}$ \\
\hline
\end{tabular}

\section{Selection}

Representativeness of the exposed cohort?

Selection of the non-exposed cohort?

Ascertainment of exposure

Demonstration that outcome of interest was not present at start of study

\section{Comparability}

Comparability of cohorts on the basis of the design or analysis

Study controls for additional risk factors?

\section{Outcome}

Assessment of outcome

Was follow-up long enough for outcomes to occur

Adequacy of follow up of cohorts
Representative of average pregnant women (age/being at risk of disease

sample size, generalizability)

Drawn from same community as exposed cohort

Depression Diagnosis in health records, structured interview

No inflammatory disease

Study controls for body mass index

Study controls for hypertensive and/or diabetes disorders

Independent blind assessment of inflammation

At least two inflammation asessments at different gestational stages

Complete follow-up, or subjects lost to

follow-up unlikely to introduce bias

(>60\% follow up, or description provided of those lost)

\section{Overall quality score (maximum=9)}

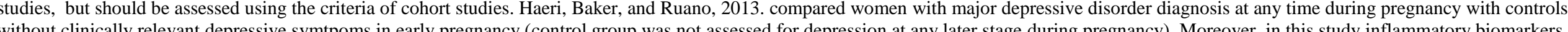

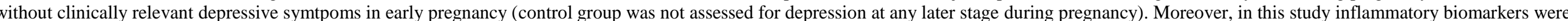

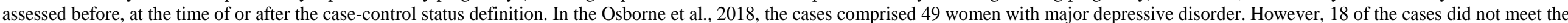
diagnostic criteria for major depressive disorder when assessed during pregnancy. Note. Quality of evidence according to the NOS-criteria for cohort studies (Wells et al., 2014a, b) were reviewed independently by Rachel Robinson and by Marius Lahti-Pulkkinen and Polina Girchenko. In cases of disagreement, they were discussed and agreed upon by consensus. 


\section{REFERENCES}

Azar, R. \& Mercer, D. (2013). Mild depressive symptoms are associated with elevated C-reactive protein and proinflammatory cytokine levels during early to midgestation: a prospective pilot study. Journal of Women's Health, 22, 385-389.

Blackmore, E. R., Moynihan, J. A., Rubinow, D. R., Pressman, E. K., Gilchrist, M. \& O'Connor, T. G. (2011). Psychiatric symptoms and proinflammatory cytokines in pregnancy. Psychosomatic Medicine, 73, 656-663.

Gustafsson, H. C., Sullivan, E. L., Nousen, E. K., Sullivan, C. A., Huang, E., Rincon, M., Nigg, J. T. \& Loftis, J. M. (2018). Maternal prenatal depression predicts infant negative affect via maternal inflammatory cytokine levels. Brain, Behavior, and Immunity, 73, 470-481.

Osborne, S., Biaggi, A., Chua, T. E., Du Preez, A., Hazelgrove, K., Nikkheslat, N., Previti, G., Zunszain, P. A., Conroy, S. \& Pariante, C. M. (2018). Antenatal depression programs cortisol stress reactivity in offspring through increased maternal inflammation and cortisol in pregnancy: The Psychiatry Research and Motherhood - Depression (PRAM-D) Study. Psychoneuroendocrinology, 98, 211-236.

Haeri, S., Baker, A. M. \& Ruano, R. (2013). Do pregnant women with depression have a pro-inflammatory profile? Journal of Obstetrics and Gynaecology Research, 39, 948952.

Wells, G., Shea, B., O'Connell, D., Peterson, J., Welch, V., Losos, M. \& Tugwell, P. (2014a). Newcastle-Ottawa quality assessment form for cohort studies. E17-E18. http://www.ncbi.nlm.nih.gov/books/NBK115843/bin/appe-fm3.pdf

Wells, G., Shea, B., O'Connell, D., Peterson, J., Welch, V., Losos, M. \& Tugwell, P. (2014b). The Newcastle-Ottawa Scale (NOS) for assessing the quality of nonrandomised studies in meta-analyses. http://www.ohri.ca/programs/clinical epidemiology/oxford.asp. 
Table ST4. Associations between moderators and covariates and high-sensitivity C-reactive protein and glycoprotein acetyls during pregnancy.

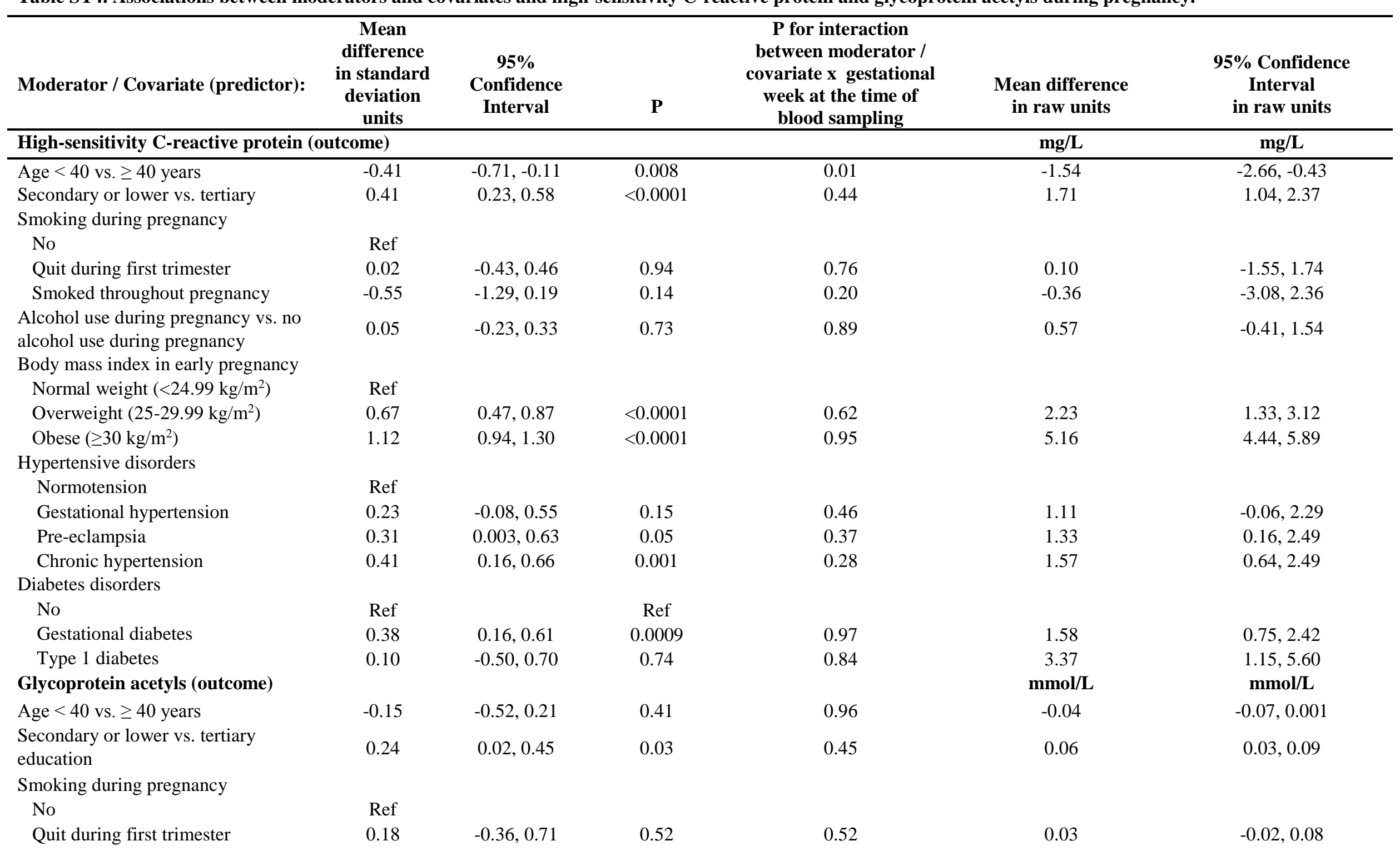




\begin{tabular}{|c|c|c|c|c|c|c|}
\hline Smoked throughout pregnancy & -0.22 & $-1.05,0.62$ & 0.61 & 0.72 & -0.01 & $-0.10,0.07$ \\
\hline $\begin{array}{l}\text { Alcohol use during pregnancy vs. no } \\
\text { alcohol use during pregnancy }\end{array}$ & 0.16 & $-0.16,0.48$ & 0.33 & 0.91 & 0.57 & $-0.41,1.54$ \\
\hline \multicolumn{7}{|l|}{ Body mass index in early pregnancy } \\
\hline Normal weight $\left(<24.99 \mathrm{~kg} / \mathrm{m}^{2}\right)$ & Ref & & & & & \\
\hline Overweight (25-29.99 kg/m²) & 0.56 & $0.30,0.82$ & $<0.0001$ & 0.01 & 0.14 & $0.12,0.17$ \\
\hline Obese $\left(\geq 30 \mathrm{~kg} / \mathrm{m}^{2}\right)$ & 0.99 & $0.77,1.22$ & $<0.0001$ & 0.84 & 0.19 & $0.17,0.21$ \\
\hline \multicolumn{7}{|l|}{ Hypertensive disorders } \\
\hline Normotension & Ref & & & & & \\
\hline Gestational hypertension & 0.08 & $-0.28,0.43$ & 0.67 & 0.31 & 0.04 & $0.001,0.07$ \\
\hline Pre-eclampsia & 0.63 & $0.28,0.98$ & 0.0005 & 0.17 & 0.09 & $0.05,0.12$ \\
\hline Chronic hypertension & 0.78 & $0.50,1.07$ & $<0.0001$ & 0.11 & 0.11 & $0.08,0.13$ \\
\hline \multicolumn{7}{|l|}{ Diabetes disorders } \\
\hline No & Ref & & Ref & & & \\
\hline Gestational diabetes & 0.48 & $0.22,0.74$ & 0.0003 & 0.34 & 0.11 & $0.08,0.13$ \\
\hline Type 1 diabetes & -0.46 & $-1.13,0.22$ & 0.18 & 0.08 & -0.01 & $-0.08,0.06$ \\
\hline
\end{tabular}


Table ST5. Associations of a history of depression diagnosis before pregnancy derived from the Care Register for Healthcare (HILMO) and self-reports, and depressive symptoms and probable clinical depression reported during pregnancy with high-sensitivity C-Reactive protein and glycoprotein acetyls across the three measurement points during pregnancy. Model includes the gestational week when blood was sampled as a within-person time-varying predictor and age, education, and diabetes and hypertensive disorders during pregnancy.

\begin{tabular}{|c|c|c|c|}
\hline & Estimate in SD units* & $95 \% \mathrm{CI}$ & $\mathrm{P}$ \\
\hline \multicolumn{4}{|c|}{ High-sensitivity C-reactive protein (SD units) (outcome) } \\
\hline \multicolumn{4}{|c|}{$\begin{array}{l}\text { History of depression diagnosis before pregnancy } \\
\text { (yes vs. no) }\end{array}$} \\
\hline from HILMO & 0.51 & $0.09,0.93$ & 0.02 \\
\hline from self-reports & 0.50 & $0.12,0.87$ & 0.009 \\
\hline \multicolumn{4}{|l|}{ Depressive symptoms during pregnancy } \\
\hline $\begin{array}{l}\text { continuous score (mean of reports at } 3 \text { blood } \\
\text { sampling points in SD units) }\end{array}$ & 0.28 & $0.04,0.52$ & 0.02 \\
\hline $\begin{array}{l}\text { binary score (continuous score } \geq 16 \text {, } \\
\text { probable clinical depression } \\
\text { vs. continuous score }<16 \text {, } \\
\text { no probable clinical depression) }\end{array}$ & 0.07 & $0.003,0.13$ & 0.04 \\
\hline \multicolumn{4}{|l|}{ Glycoprotein acetyls (SD units) (outcome) } \\
\hline \multicolumn{4}{|l|}{$\begin{array}{l}\text { History of depression diagnosis } \\
\text { before pregnancy (yes vs. no) }\end{array}$} \\
\hline from HILMO & 0.43 & $0.05,0.82$ & 0.03 \\
\hline from self-reports & 0.31 & $-0.02,0.64$ & 0.07 \\
\hline \multicolumn{4}{|l|}{ Depressive symptoms during pregnancy } \\
\hline $\begin{array}{l}\text { continuous score (mean of reports at } 3 \text { blood } \\
\text { sampling points in SD units) }\end{array}$ & 0.18 & $-0.02,0.37$ & 0.07 \\
\hline $\begin{array}{l}\text { binary score (continuous score } \geq 16 \text {, } \\
\text { probable clinical depression } \\
\text { vs. continuous score }<16 \text {, } \\
\text { no probable clinical depression) }\end{array}$ & 0.05 & $-0.01,0.11$ & 0.08 \\
\hline \multicolumn{4}{|c|}{$\begin{array}{l}\text { Note. *Estimates and 95\% Confidence Intervals (95\% CI) reflect differences between those with and without a } \\
\text { history of depression diagnosis before pregnancy or with and without probable clinical depression during } \\
\text { pregnancy in high-sensitivity C-reactive protein (hsCRP) and glycoprotein acetyls in standard deviation (SD) units } \\
\text { or change in SD units in hsCRP and glycoprotein acetyls per SD unit change in the continuous depressive } \\
\text { symptoms score during pregnancy. }\end{array}$} \\
\hline
\end{tabular}


Table ST6. Associations of a history of depression diagnosis before pregnancy derived from the Care Register for Healthcare (HILMO) and self-reports, and depressive symptoms and probable clinical depression reported during pregnancy with high-sensitivity C-Reactive protein and glycoprotein acetyls across the three measurement points during pregnancy. Sensitivity analyses excluding blood samples which occurred within a month preceding or following acute infectious disease diagnoses derived from HILMO.

\begin{tabular}{|c|c|c|c|}
\hline & Estimate in SD units* & $95 \% \mathrm{CI}$ & $\mathrm{P}$ \\
\hline \multicolumn{4}{|c|}{ High-sensitivity C-reactive protein (SD units) (outcome) } \\
\hline \multicolumn{4}{|l|}{ History of depression diagnosis } \\
\hline \multicolumn{4}{|l|}{ before pregnancy (yes vs. no) } \\
\hline from HILMO $* *$ & 0.70 & $0.27,1.12$ & 0.001 \\
\hline from self-reports $* * *$ & 0.57 & $0.18,0.95$ & 0.004 \\
\hline \multicolumn{4}{|l|}{ Depressive symptoms during pregnancy } \\
\hline $\begin{array}{l}\text { continuous score (mean of reports at } 3 \text { blood } \\
\text { sampling points in SD units) } * * * *\end{array}$ & 0.06 & $0.0001,0.13$ & 0.05 \\
\hline $\begin{array}{l}\text { binary score (continuous score } \geq 16 \text {, } \\
\text { probable clinical depression }\end{array}$ & 0.27 & $0.02,0.52$ & 0.03 \\
\hline \multicolumn{4}{|l|}{ vs. continuous score $<16$, } \\
\hline \multicolumn{4}{|l|}{ Glycoprotein acetyls (SD units) (outcome) } \\
\hline \multicolumn{4}{|l|}{ History of depression diagnosis } \\
\hline from HILMO** & 0.49 & $0.09,0.90$ & 0.02 \\
\hline from self-reports $* * *$ & 0.29 & $-0.07,0.64$ & 0.12 \\
\hline \multicolumn{4}{|l|}{ Depressive symptoms during pregnancy } \\
\hline $\begin{array}{l}\text { continuous score (mean of reports at } 3 \text { blood } \\
\text { sampling points in SD units) } * * * *\end{array}$ & 0.05 & $-0.001,0.11$ & 0.09 \\
\hline $\begin{array}{l}\text { binary score (continuous score } \geq 16 \text {, } \\
\text { probable clinical depression }\end{array}$ & 0.25 & $0.02,0.47$ & 0.04 \\
\hline \multicolumn{4}{|l|}{ vs. continuous score $<16$, } \\
\hline \multicolumn{4}{|c|}{$\begin{array}{l}\text { Note. *Estimates and 95\% Confidence Intervals }(95 \% \text { CI) reflect differences between those with and without a } \\
\text { history of depression diagnosis before pregnancy or with and without probable clinical depression during } \\
\text { pregnancy in high-sensitivity C-reactive protein }(\mathrm{hsCRP}) \text { and glycoprotein acetyls in standard deviation }(\mathrm{SD}) \text { units } \\
\text { or change in SD units in hSCRP and glycoprotein acetyls per SD unit change in the continuous depressive } \\
\text { symptoms score during pregnancy. } \\
* * 13 \text { measurements were excluded out of a total of } 1125 \text { measurements in the analytic sample }(\mathrm{n}=375) \text {. } \\
* * * 11 \text { measurements were excluded out of a total of } 1041 \text { measurements in the analytic sample }(\mathrm{n}=347) \text {. } \\
* * * * 6 \text { measurements were excluded out of a total of } 885 \text { measurements in the analytic sample }(\mathrm{n}=295) \text {. }\end{array}$} \\
\hline
\end{tabular}


Figure ST1. Change in high-sensevbly C-reactive protein (Panel A) and grycoprotein acetyts durng pregnancy. (Panet B).

Panel A.

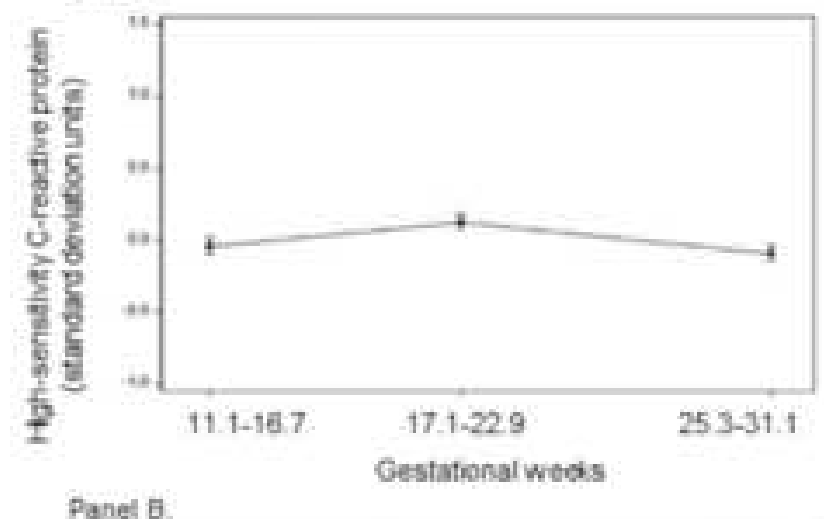

Panel 6

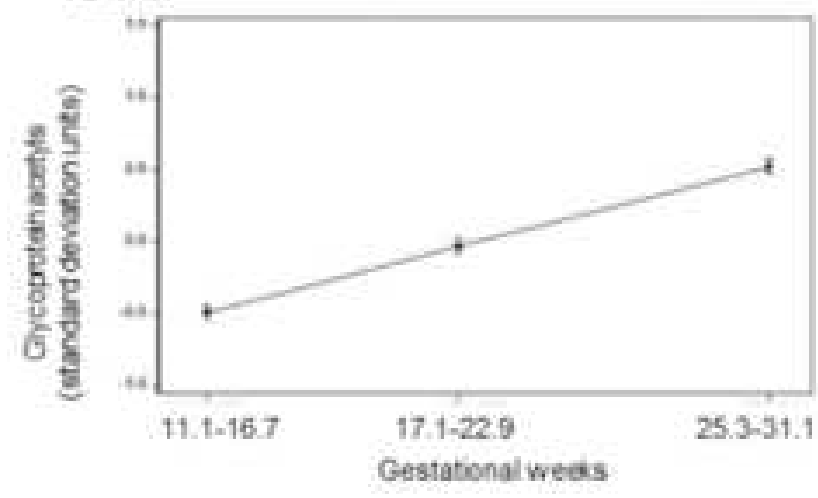




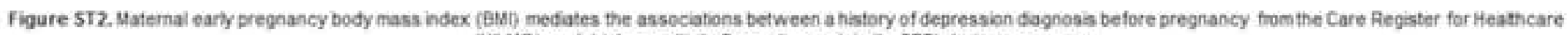
(HILMO) and high-senstivty C-reactive protein (hsCRP) during pregnancy.

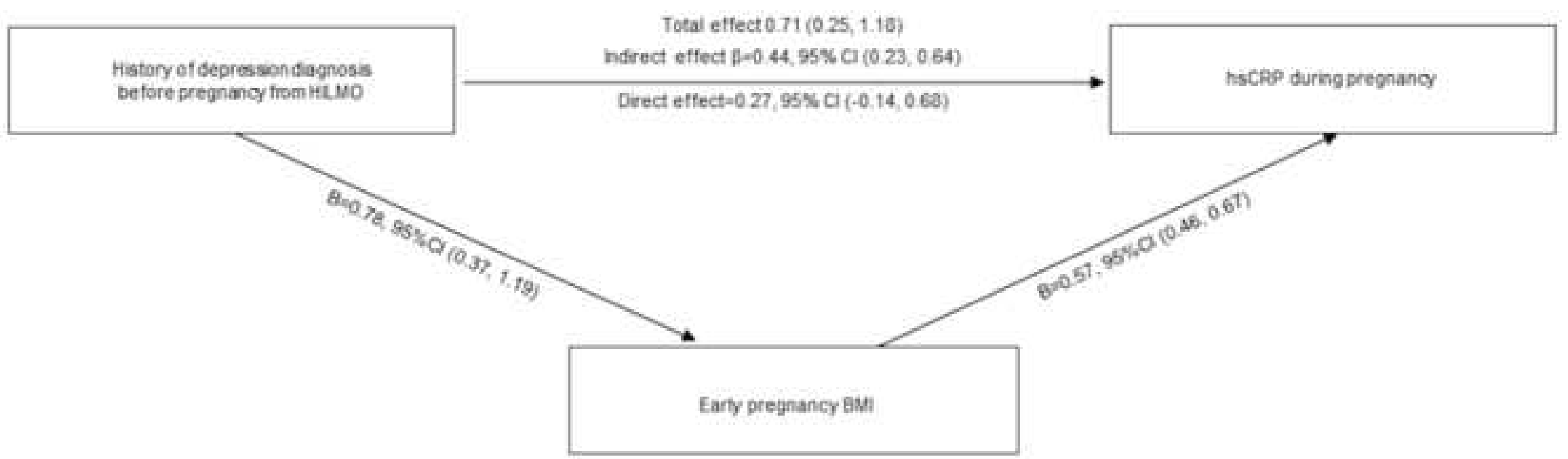


Figure 5T3. Maternal early prephancy body mass index (BM) mediates the associations between a history of depression diagnosis be fore pregnancy from seif-reports and high-senstivity C-teactive proten (hSCRP) during pregnancy.

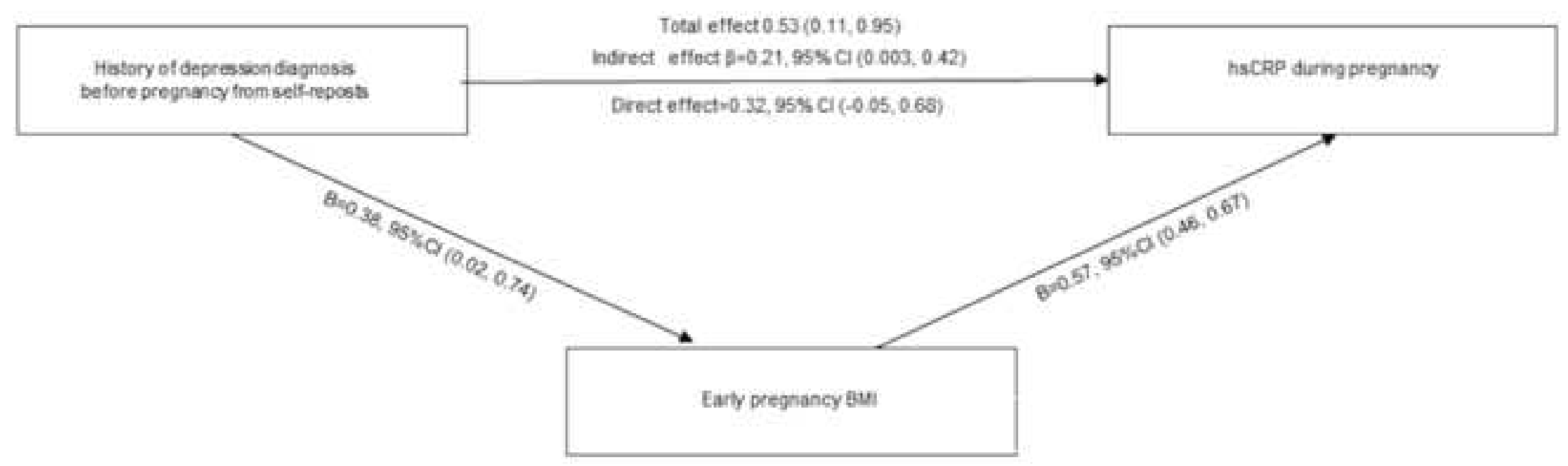


Figure ST 4. Uaternai early pregnancy body mass index (BM) mediates the association between depressive symptoms during pregnancy and high-sensitivity C-teactive proten (hsCRP) during pregnancy

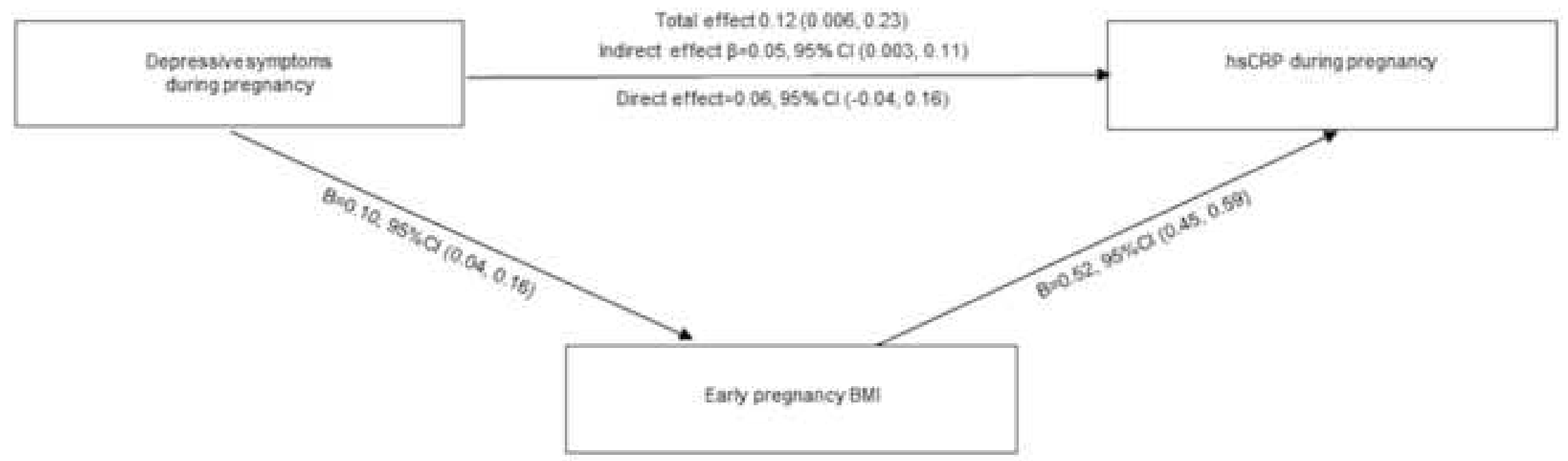

Total effect $0.12(0.006,0.23)$

Depressivesymptana ndrect effect $\beta=0.05,95 \% \mathrm{Cr}(0.003,0.11)$

Earty pregnancy BW. 
Figure 5TS. Maternal earty pregnancy body mass index (BMI) medates the associations between a history of depressian dagnosis before pregnancy from the Care Register for Heathcare (0RLWO) and gycoprotein acetyls durng pregnascy

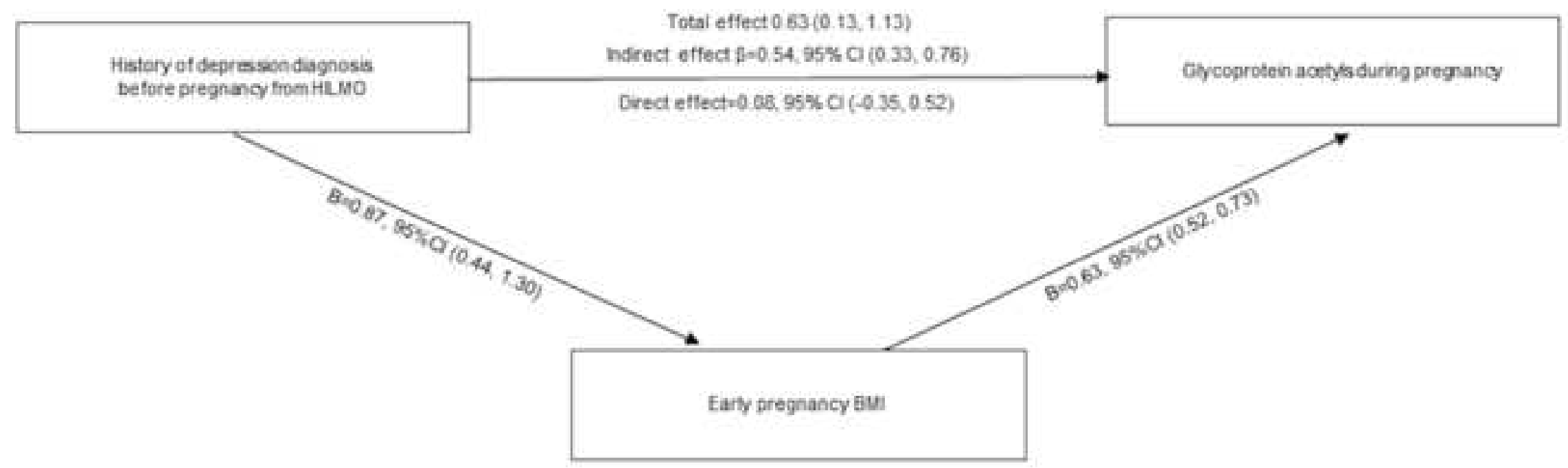


Figure ST6. Lowess curve showing the association between early pregnaricy body mass index (BU) and high-senstivty $C$-reactve proten durng pregnancy

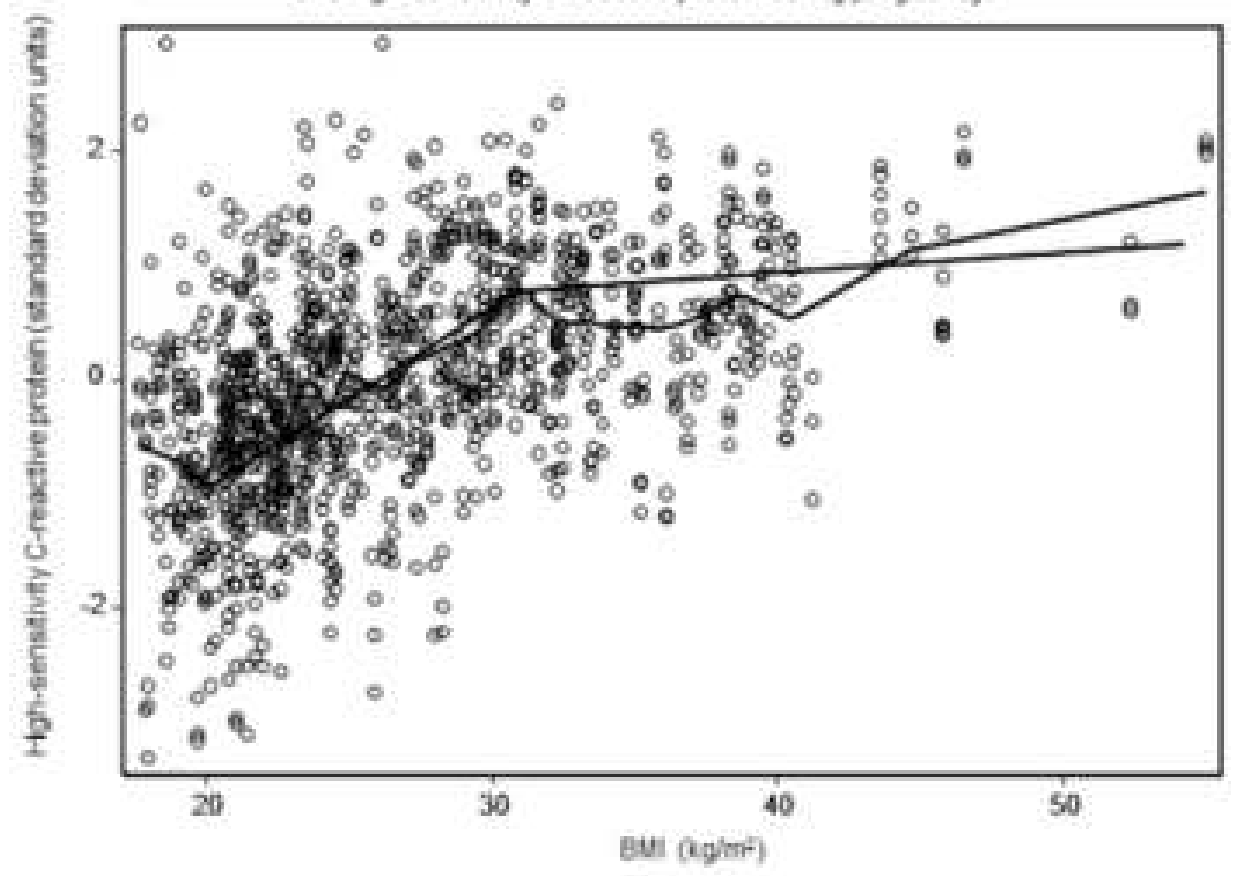

